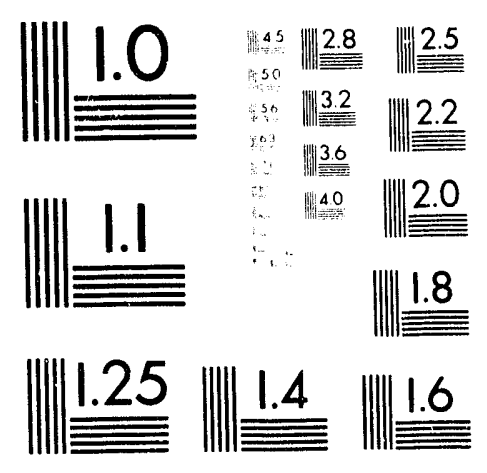



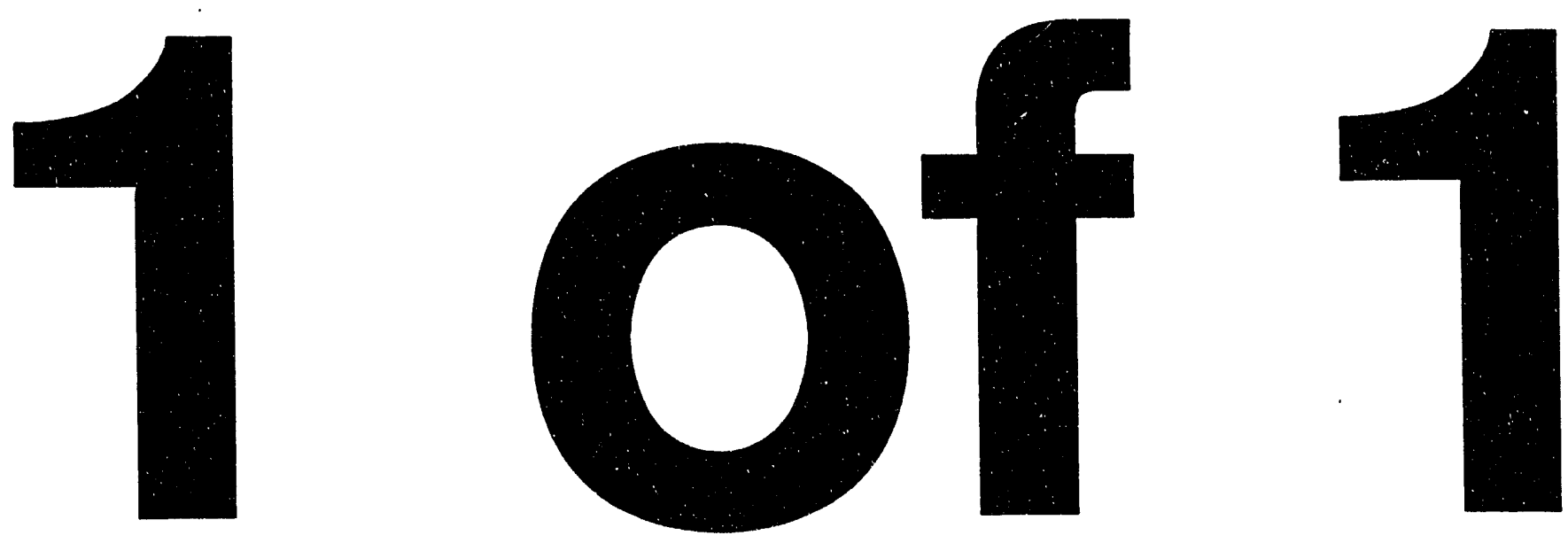
Metals and Ceramics Division

\title{
ALLOYING EFFECTS ON MECHANICAL AND METALLURGICAL PROPERTIES OF NiAl
}

\author{
C. T. Liu \\ J. A. Horton \\ E. H. Lee \\ E. P. George
}

Date Prepared: October 1990

Date Published: June 1993

NOTICE: This document contains information of a preliminary nature. It is subject to revision or correction and therefore does not represent a final report.

Prepared for the

U.S. Department of Energy

Assistant Secretary for Conservation and Renewable Energy

Office of Industrial Technologies

Advanced Industial Concepts Materials Program

ED 3802000

Prepared by the

OAK RIDGE NATIONAL LABORATORY

Oak Ridge, Tennessee 37831-6285

managed by

MARTIN MARIETTA ENERGY SYSTEMS, INC.

for the

U.S. DEPARTMENT OF ENERGY

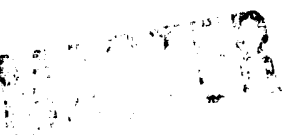


TABLE OF CONTENTS

Page

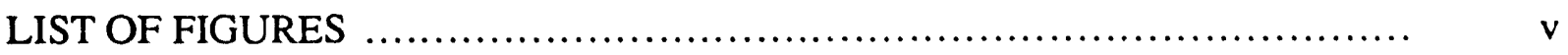

LIST OF TABLES ............................................................. vii

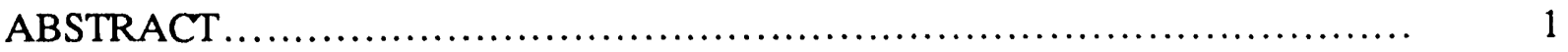

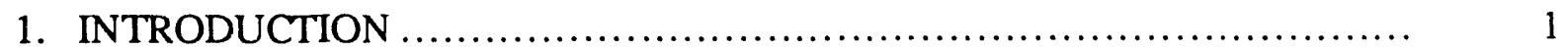

2. MICROALLOYING OF STOICHIOMETRIC NiAl................................ 2

3. PREPARATION AND FABRICATION OF MACROALLOYED NiAl .......... 3

4. EFFECTS OF ALLOY ADDITIONS (EXCLUDING Mo, W, AND V)........... 6

5. ALLOYING EFFECTS OF Mo, W, AND V ................................ 6

6. INITIAL ALLOY DEVELOPMENT OF NiAl ALLOYS............................. 15

7. TEM STUDY OF NiAl ALLOYS ............................................. 17

8. CREEP PROPERTIES OF NiAI ALLOYS .................................. 22

9. OXIDATION PROPERTIES .......................................... 22

10. SUMMARY AND CONCLUSIONS ..................................... 24

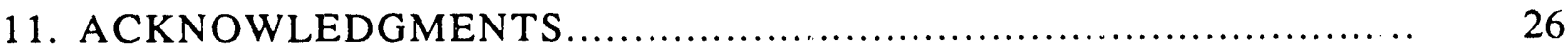

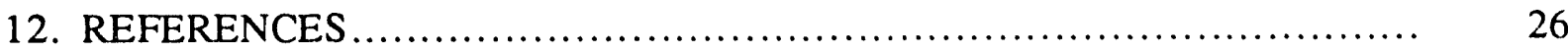




\section{LIST OF FIGURES}

Figure

Page

1 The location of alloying elements (added to $\mathrm{NiAl}$ ) in a modified periodic chart.

2 Optical micrograph of $\mathrm{NiAl}$ alloys: (a) NAL-41, $\mathrm{NiAl}+5 \% \mathrm{Fe}$, annealed $1 \mathrm{~h}$ at $900^{\circ} \mathrm{C}$, and $(b) \mathrm{NAL}-48, \mathrm{NiAl}+0.4 \% \mathrm{Ti}$, annealed $1 \mathrm{~h}$ at $1000^{\circ} \mathrm{C}$

3 Optical micrographs of NAL- 44 (NiAl + 0.4\% Mo): (a) anneal $1 \mathrm{~h}$ at $1000^{\circ} \mathrm{C}$, partially recrystallized, and $(b)$ anneal $1 \mathrm{~h}$ at $1200^{\circ} \mathrm{C}$, completely recrystallized.

4 Back-scattered electron micrograph showing the formation of molybdenum-rich particles in NAL-55 (NiAl + 0.7\% Mo)

5 SEM fractograph of NAL-44 (NiAl $+0.4 \% \mathrm{Mo})$ annealed $1 \mathrm{~h}$ at $1200^{\circ} \mathrm{C}$, showing a mixed fracture mode

6 Comparison of tensile properties of stoichiometric $\mathrm{NiAl}$ with the alloy NAL-44 containing $0.4 \%$ Mo

7 SEM fractograph of NAL-61 (NiAl + 1.5\% Mo + 0.4\% Ta, at. \%)

fractured at room temperature

8 Microstructure of NAL-59 (NiAl $+1.5 \% \mathrm{Mo}+0.4 \% \mathrm{Nb}$, at. \%) annealed for $1 \mathrm{~h}$ at $1300^{\circ} \mathrm{C}$ : (a) optical micrograph and $(b)$ back-scattered electron micrograph

9 TEM micrograph of alloy NAL-55 after an anneal of $1 \mathrm{~h}$ at $1200^{\circ} \mathrm{C}$ and a strain of $1.3 \%$ showing precipitate and dislocation distribution

10 TEM micrograph of alloy NAL-61 after an anneal of $1 \mathrm{~h}$ at $1300^{\circ} \mathrm{C}$ and a strain of $2.9 \%$

11 TEM micrograph of a dislocation spiral in NAL-59 that nucleated on a second-phase precipitate from a vacancy condensation mechanism. The spiral is a prismatic edge loop with a Burgers vector of [001]. Figure $11(a)$ is looking straight on the [001] habit plane of the spiral. The dislocation is in residual contrast since $\mathrm{g} \cdot \mathrm{b}=0$. In Fig. $11(b)$, the specimen is tilted so that the intersection of the spiral with the precipitate can be seen. The electron beam direction is [101] and $\mathrm{g}=[\overline{1} 01]$

12 Plot of weight change as a function of exposure time for $\mathrm{NiAl}$ alloys exposed to air at $800^{\circ} \mathrm{C}$ 
13 Plot of weight change as a function of exposure time for NiAl alloys

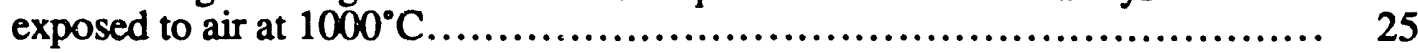




\section{LIST OF TABLES}

Table

Page

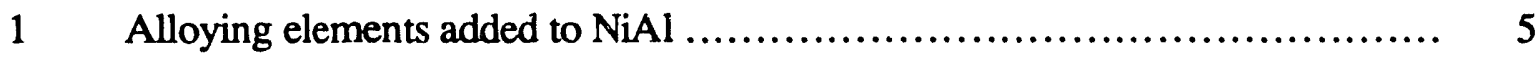

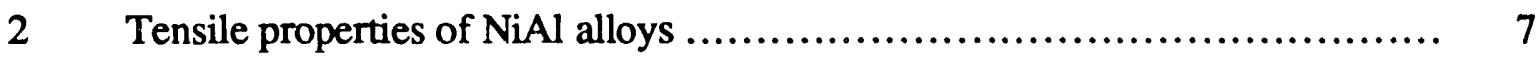

3 Results of electron microprobe analyses of matrix and second-phase particles in $\mathrm{NiAl}$ alloys $. . \ldots \ldots \ldots \ldots \ldots \ldots \ldots \ldots \ldots \ldots \ldots \ldots \ldots, 11$

4 Effect of heat treatment on room-temperature tensile properties on NAL-44 (NiAl + 0.4\% Mo)

5 Effect of molybdenum additions on tensile properties of $\mathrm{NiAl}$ alloys

6 Effect of boron doping on tensile properties of $\mathrm{NiAl}$ containing 0.4 at. \% Mo

7 Effect of 0.4 at. \% vanadium, molybdenum, or tungsten on tensile properties of $\mathrm{NiAl}$

8 Tensile properties of complex NiAl alloys 16

9 TEM compositional analysis by EDS 19

10 Creep properties of $\mathrm{NiAl}$ alloys tested at $68.9 \mathrm{MPa}(10 \mathrm{ksi})$ and $816^{\circ} \mathrm{C}\left(1500^{\circ} \mathrm{F}\right)$ in air....

11 Creep properties of $\mathrm{NiAl}$ alloys tested at $130 \mathrm{MPa}(20 \mathrm{ksi})$ and $816^{\circ} \mathrm{C}\left(1500^{\circ} \mathrm{F}\right)$ 


\title{
ALLOYING EFFECTS ON MECHANICAL AND METALLURGICAL PROPERTIES OF NiAl*
}

\author{
C. T. Liu, J. A. Horton, E. H. Lee, and E. P. George
}

\begin{abstract}
Alloying effects have been investigated in near-stoichiometric $\mathrm{NiAl}$ for the purpose of improving its mechanical and metallurgical properties. Ternary additions of 19 elements at levels up to 10 at. \% were added to $\mathrm{NiAl}$; among them, molybdenum is found to be most effective in improving the roomtemperature ductility and high-temperature strength. Alloying with $1.0 \pm 0.6 \%$ molybdenum almost doubles the room-temperature tensile ductility of $\mathrm{NiAl}$ and triples its yield strength at $1000^{\circ} \mathrm{C}$. The creep properties of molybdenum-modified $\mathrm{NiAl}$ alloys can be dramatically improved by alloying with up to $1 \%$ of niobium or tantalum. Because of the low solubilities of molybdenum and niobium in $\mathrm{NiAl}$, the beneficial effects mainly come from precipitation hardening. Fine and coarse precipitates are revealed by both transmission electron microscopy (TEM) and electron microprobe analyses. Molybdenum-containing alloys possess excellent oxidation resistance and can be fabricated into rod stock by hot extrusion at 900 to $1050^{\circ} \mathrm{C}$. This study of alloying effects provides a critical input for the alloy design of ductile and strong NiAl aluminide alloys for high-temperature structural applications.
\end{abstract}

\section{INTRODUCTION}

$\mathrm{NiAl}$ alloys containing more than 40 at. \% nickel form a single-phase B2-type ordered crystal structure based on the body-centered cubic (bcc) lattice. ${ }^{1}$ In terms of physical properties, $\mathrm{B} 2-\mathrm{NiAl}$ offers more potential for high-temperature applications than $\mathrm{Ll}_{2}-\mathrm{Ni}_{3} \mathrm{Al}$. It has a higher melting point $\left(\mathrm{T}_{\mathrm{m}}=1638^{\circ} \mathrm{C}\right.$ for $\mathrm{NiAl}$ vs $1395^{\circ} \mathrm{C}$ for $\left.\mathrm{Ni}_{3} \mathrm{Al}\right)$, a substantially lower density $(5.86 \mathrm{~g} / \mathrm{cc}$ vs $7.50 \mathrm{~g} / \mathrm{cc})$, and a higher Young's modulus $\left(42.7 \times 10^{6}\right.$ vs $25.9 \times$ $\left.10^{6} \mathrm{psi}\right)$. In addition, $\mathrm{NiAl}$ offers excellent oxidation resistance at high temperatures. 2,3 In

*Research sponsored by the U.S. Department of Energy, Assistant Secretary for Conservation and Renewable Energy, Office of Industrial Technologies, Advanced Industrial Concepts (AIC) Materials Program, under contract DE-AC05-84OR21400 with Martin Marietta Energy Systems, Inc. 
the 1950s and 1960s, NiAl alloys were used as a coating material for hot components in corrosive environments. The oxidation resistance of $\mathrm{NiAl}$ can be further improved by alloying with yttrium and other refractory elements such as hafnium and zirconium. 4,5

The use of $\mathrm{NiAl}$ as structural members, however, suffers from two major drawbacks: (1) poor ductility at ambient temperatures and (2) low strength and creep resistance at elevated temperatures. Single crystals of $\mathrm{NiAl}$ are quite ductile in compression, but both single and polycrystalline $\mathrm{NiAl}$ appear to be brittle in tension at room temperature. ${ }^{6-8} \mathrm{The}$ nickel aluminide exhibits mainly $<100>$ slip, ${ }^{9-11}$ rather than the $<111>$ slip that is commonly observed for bcc materials. The lack of sufficient slip systems has been regarded as a major cause for the low ductility of NiAl. 6-8 The aluminide shows a sharp increase in ductility above $400^{\circ} \mathrm{C}$ and becomes very ductile above $600^{\circ} \mathrm{C} .12,13$ Hence, there is no major problem in the fabrication of NiAl. At higher temperatures, $\mathrm{NiAl}$ is highly ductile but weak in strength. For instance, $\mathrm{Ni}-50$ at. \% $\mathrm{Al}$ has a yield strength of $35 \mathrm{MPa}$ and a tensile ductility of $>50 \%$ at $1000^{\circ} \mathrm{C}$.

During the past 30 years, considerable effort has been devoted to improving the ductility of NiAl alloys at ambient temperatures. ${ }^{6-8,12}$ After an early report in 1966 of limited (2\%) room-temperature tensile ductility in polycrystalline $\mathrm{NiAl},{ }^{14}$ numerous later attempts to reproduce this ductility were unsuccessful until Hahn and Vedula ${ }^{13}$ recently showed that it was possible to obtain room-temperature plastic elongation of $2.5 \%$ in nearly stoichiometric, cast and extruded $\mathrm{NiAl}$. Although it is not completely clear why the previous attempts were unsuccessful, it is now routinely possible to obtain plastic elongations of 2 to $3 \%$ in cast and extruded stoichiometric NiAl. 15,16 Perhaps some of the earlier unsuccessful attempts, especially those using the powder metallurgy approach, ${ }^{17}$ were plagued by interstitial element problems. Small deviations from stoichiometry, however, result in a complete loss of the tensile ductility. ${ }^{13}$ This embrittlement effect has been attributed to point defects generated in off-stoichiometric NiAl. ${ }^{15,16}$ It is known that deviations from stoichiometry are accommodated by the incorporation of vacancies in aluminum-rich alloys and by formation of anti-site defects in nickel-rich NiAl. ${ }^{18-21}$ The presence of these defects substantially hardens $\mathrm{NiAl}$ at ambient temperatures, 22 thereby reducing its ductility. 15,16

\section{MICROALLOYING OF STOICHIOMETRIC NiAI}

This section briefly summarizes our work on microalloying of NiAl.15,16 The fracture mode of polycrystalline $\mathrm{NiAl}$ with the stoichiometric composition is predominantly intergranular at ambient temperatures. Our detailed Auger analyses showed that grain 
boundaries in $\mathrm{NiAl}$ are extremely clean and free of impurities. This implies that grain boundaries in $\mathrm{NiAl}$ are intrinsically brittle, like those in $\mathrm{Ni}_{3} \mathrm{Al}^{23-25}$

In an early study, microalloying elements such as $\mathrm{B}, \mathrm{C}$, and $\mathrm{Be}$ were added to $\mathrm{NiAl}$ for improving its fracture behavior. ${ }^{15}$ We have found that microalloying with boron at levels to $300 \mathrm{wppm}(0.12$ at. \%) is able to completely suppress this intergranular fracture. Auger analysis confirmed that the beneficial effect of boron is due to its strong segregation at grain houndaries. Unlike in $\mathrm{Ni}_{3} \mathrm{Al}, 23,26-27$ however, the suppression of grain-boundary fracture is not accompanied by an increase in ductility. On the contrary, because of its strong solidsolution strengthening effect in NiAl, addition of too much boron can actually cause embrittlement. 15,16

A measurement of the yield strength as a function of boron concentration yields a solid-solution hardening value of $\sim 4500 \mathrm{MPa} /$ at. $\% \mathrm{~B}$, due to boron additions. Thus, boron is an extremely potent solid-solution strengthener in NiAl. As a result, any potential benefit of improved grain-boundary strength is more than offset by an increase in yield strength. For instance, if greater than about 100 wppm boron $(0.04$ at. \% B) is added to $\mathrm{NiAl}$, the aluminide fractures by transgranular cleavage before macroscopic yielding can take place. The observation of cleavage: fracture suggests that poor cohesive strength across crystallographic planes is another major cause for brittle fracture and low ductility of NiAl. 15,16

Unlike boron, both carbon (300 wppm) and beryllium (500 wppm) are ineffective in suppressing intergranular fracture in $\mathrm{NiAl}$, and Auger analyses of the carbon-doped alloy revealed that carbon did not affect the fracture mode bec ause it did not segregate to the grain boundaries. ${ }^{15}$ Although neither beryllium nor carbon suppresses grain-boundary fracture, their effects on the tensile ductility of NiAl were quite different. The ductility of the berylliumdoped alioy was higher than that of the boron-doped alloy because beryllium, unlike boron, has a rather modest strengthening effect in NiAl, whereas the carbon-doped alloy was brittle like the boron-doped alloy because carbon is a potent solid-solution strengthener, just like boron. These observations were rationalized by considering a hard-sphere model for interstitial and substitutional sites in NiAl. ${ }^{15}$ Our studies also showed that the nickel and aluminum concentrations of the grain boundaries were not significantly different from the bulk levels, and no evidence was found for Ni-B cosegregation. 15,16

\section{PREPARATION AND FABRICATION OF MACROALLOYED NiAI}

The foregoing section indicates that microalloying with boron suppresses brittle grain-boundary fracture, but it does not increase the tensile ductility of stoichiometric NiAl. 
This suggests the need to improve bulk properties of $\mathrm{NiAl}$, in terms of improved cleavage strength and increased slip systems. Macroalloying was thus adopted in this study to alter the bulk properties at room and elevaicui temperatures.

In this study, 12 elements were selected for alloying with $\mathrm{NiAl}$. The selection of alloying elements was based on considerations of electronic structure, atom bonding, solubility limit, and antiphase boundary (APB) energy. The location of these elements is shown in a modified periodic chart, $28-30$ which ranges from groups IIIA to IIIB (see Fig. 1).

$\mathrm{NiAl}$ alloys containing up to 10 at. \% of the alloying elements were prepared by arc melting using commercial-purity nickel, aluminum, and alloying metals. The elements listed in Table 1 were chosen to replace nickel, aluminum, or both, based on their chemical behavior.

ORNL-DWG 90-14946

\begin{tabular}{|c|c|c|}
\hline 0 & $1 \mathrm{~A}$ & \\
\hline 1 & 12 & \\
\hline $\mathrm{He}$ & $\mathrm{Li}$ & \\
\hline $\begin{array}{c}2 \\
\mathrm{Ne}\end{array}$ & $\begin{array}{l}11 \\
\text { No }\end{array}$ & IIA \\
\hline 3 & 10 & 16 \\
\hline Ar & $K$ & $\mathrm{Ca}$ \\
\hline 4 & 9 & 15 \\
\hline $\mathrm{Kr}$ & $\mathrm{Rb}$ & $\mathrm{Sr}$ \\
\hline 5 & 8 & 14 \\
\hline$X e$ & Cs & $\mathrm{Ba}$ \\
\hline 6 & 7 & 13 \\
\hline $\mathrm{Rn}$ & $\mathrm{Fr}$ & $\mathrm{Ra}$ \\
\hline
\end{tabular}

IIB IIIB NB VB VIB VIIB

$\begin{array}{llllll}77 & 86 & 95 & 100 & 101 & 102\end{array}$

$\begin{array}{llllll}\mathrm{Be} & \mathrm{B} & \mathrm{C} & \mathrm{N} & \mathrm{O} & \mathrm{F}\end{array}$

$\begin{array}{llllll}73 & 80 & 85 & 90 & 94 & 99\end{array}$

$\begin{array}{cc}2 & 11 \\ \mathrm{Ne} & \mathrm{No}\end{array}$ IIA IIIA IVA VA VIA VIIAVIIIa VIIIb VIII IB $\begin{array}{llllll}73 & 80 & 85 & 90 & 94 & 99 \\ \mathrm{Mg} & \mathrm{Al} & \mathrm{Si} & \mathrm{P} & \mathrm{S} & \mathrm{Cl}\end{array}$

\begin{tabular}{llllllllllllll|llll}
3 & 10 & 16 & 19 & 51 & 54 & 57 & 60 & 61 & 64 & 67 & 72 & 76 & 81 & 84 & 89 & 93 & 98
\end{tabular}

Ar $\mathrm{K}$ Ca Sc $\mathrm{Ti} \vee \mathrm{Cr} \quad \mathrm{Mn} \mathrm{Fe}$ Co $\mathrm{Ni} \mathrm{Cu} \quad \mathrm{Zn}$ Ga $\mathrm{Ge}$ As $\mathrm{Se} \quad \mathrm{Br}$

\begin{tabular}{lll|lllllllll|lllllll}
4 & 9 & 15 & 25 & 49 & 53 & 56 & 59 & 62 & 65 & 69 & 71 & 75 & 79 & 83 & 88 & 92 & 97
\end{tabular}

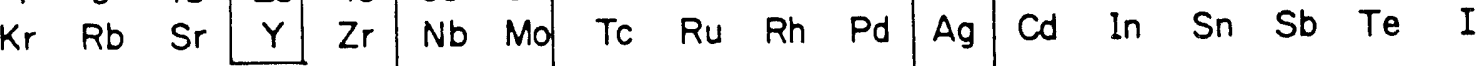

$\begin{array}{lll}5 & 8 & 14\end{array} \quad \begin{array}{lllllllllllllll}50 & 52 & 55 & 58 & 63 & 66 & 68 & 70 & 74 & 78 & 82 & 87 & 91 & 96\end{array}$

$\mathrm{Hf}$ Ta $W$ Re Os Ir Pt $\mathrm{Au}$ Hg $\mathrm{TI}$ Pb $\mathrm{Bi}$ Po At

Fig. 1. The location of alloying elements (added to $\mathrm{NiAl}$ ) in a modified periodic chart. 
Table 1. Initial alloying elements added to NiAl

\begin{tabular}{|c|c|c|c|c|c|c|c|}
\hline \multirow{2}{*}{$\begin{array}{l}\text { Elements } \\
\mathrm{Fe}\end{array}$} & \multicolumn{7}{|c|}{ Concentration (at. \%) } \\
\hline & $2.0^{a}$ & $2.0^{c}$ & $5.9^{a}$ & $10.0^{a}$ & & & \\
\hline Mo & $0.2^{a}$ & $0.4^{a}$ & $0.7 c$ & $1.0 c$ & $1.5^{c}$ & $2.0^{C}$ & $3.0^{c}$ \\
\hline $\mathrm{Cr}$ & $1.0^{a}$ & & & & & & \\
\hline $\mathrm{Ga}$ & $1.0^{b}$ & & & & & & \\
\hline $\mathrm{Ti}$ & $0.4^{b}$ & & & & & & \\
\hline V & $0.4^{c}$ & & & & & & \\
\hline$Y$ & $0.0025^{c}$ & & & & & & \\
\hline W & $0.4^{a}$ & & & & & & \\
\hline $\mathrm{Mn}$ & $1.0^{a}$ & & & & & & \\
\hline $\mathrm{Cu}$ & $2.0^{a}$ & & & & & & \\
\hline $\mathrm{Ag}$ & $2.0 a$ & & & & & & \\
\hline $\mathrm{Zn}$ & $10.0^{a}$ & $10.0^{b}$ & & & & & \\
\hline
\end{tabular}

aSubstitution for Ni atoms.

bSubstitution for $\mathrm{Al}$ atoms.

cSubstitution for both $\mathrm{Ni}$ and $\mathrm{Al}$ atoms.

The ingots were drop-cast into cylindrical copper chill molds $25.4 \mathrm{~mm}$ in diameter and $102 \mathrm{~mm}$ in length. After sectioning the head, the cast ingots were canned in mild steels and extruded at $900^{\circ} \mathrm{C}$ at a ratio of 9:1. Most alloys were successfully extruded to 8-mm-diam rod stock without difficulty.

Buttonhead tensile specimens with a diameter of $3.2 \mathrm{~mm}$ in the $17.8-\mathrm{mm}$-long gage section were ground from the extruded rods; electropolished for $120 \mathrm{~s}$ at 6 to $7 \mathrm{~V}$ in a solution of $13 \% \mathrm{H}_{2} \mathrm{SO}_{4}$ in methanol alcohol; and annealed in vacuum for $1 \mathrm{~h}$ at various temperatures to produce stress-relieved, partially recrystallized or fully recrystallized grain structures for mechanical property evaluation. Most specimens were given a final anneal of $1 \mathrm{~h}$ at $800^{\circ} \mathrm{C}$ to reduce point defects.

Tensile tests were performed in air at temperatures to $1000^{\circ} \mathrm{C}$ using a screw-driven Instron machine operated at an engineering strain rate of $2.4 \times 10^{-3} / \mathrm{s}$. The test temperature was monitored by a $\mathrm{Pt} / \mathrm{Pt}-10 \% \mathrm{Rh}$ thermocouple. The strain was measured from a strip chart. Subsequently, the fracture surfaces were examined in a JEOL JSM-35CF scanning electron microscope operated at $25 \mathrm{kV}$. Creep tests were performed on the same type of specimens, and creep stress was calculated based on a dead-load arrangement. 


\section{EFFECTS OF ALLOY ADDITIONS (EXCLUDING Mo, W, AND V)}

All alloys were successfully prepared, except the alloys containing silver and zinc*. Because of extremely high vapor pressures of zinc and silver, evaporation loss during arc melting masked furnace viewports and sometimes even caused a small explosion inside the furnace. All \% symbols in this section and remaining sections refer to at. $\%$ for clarity. No tensile specimens could be prepared from the hot-extruded rods of the alloys containing $1 \% \mathrm{Cr}$, $1 \% \mathrm{Mn}, 2 \% \mathrm{Cu}$, or $10 \% \mathrm{Fe}$ (all at. \%) because they cracked during grinding. Consequently, there are no property data available from these alloys. Miracle et al. ${ }^{31}$ reported that chromium and manganese change the slip systems but do not impart any ductility to NiAl.

Alloy specimens, with their nominal composition listed in Table 2, were annealed for $1 \mathrm{~h}$ at 880 to $1000^{\circ} \mathrm{C}$ to produce a recrystallized grain structure for evaluation of their mechanical properties. Figures $2(a)$ and $(b)$ show the microstructure of the alloys containing $5 \% \mathrm{Fe}$ and $0.4 \% \mathrm{Ti}$. Second-phase particles appear to be present in the $0.4 \% \mathrm{Ti}$ alloy. Tensile properties of the $\mathrm{NiAl}$ alloys tested at room temperature, 600 , and $1000^{\circ} \mathrm{C}$ are summarized in Table 2. Alloying with $2 \% \mathrm{Fe}$ increases the strength but lowers the ductility at room temperature. Alloying with $5 \% \mathrm{Fe}$ completely embrittles NiAl. The addition of $2 \% \mathrm{Fe}$ only slightly strengthens $\mathrm{NiAl}$ at 600 and $1000^{\circ} \mathrm{C}$.

The $\mathrm{NiAl}$ alloy showed a slight increase in room-temperature ductility when alloyed with $1.0 \% \mathrm{Ga}$ or $0.4 \% \mathrm{Ti}$ but exhibited a slight decrease in ductility when alloyed with $0.0025 \% \mathrm{Y}$. Among the alloying elements listed in Table 2, titanium is most effective in strengthening of $\mathrm{NiAl}$ at 600 and $1000^{\circ} \mathrm{C}$. All the alloys showed good ductility at elevated temperatures, except for the $2 \% \mathrm{Fe}$ alloy that fractured with an elongation of only $6.7 \%$ at $600^{\circ} \mathrm{C}$.

\section{ALLOYING EFFECTS OF Mo, W, AND V}

Molybdenum at levels up to 3 at. \% was added to NiAl to study its alloying effect. Unalloyed $\mathrm{NiAl}$ recrystallizes at $800^{\circ} \mathrm{C}$ after $1 \mathrm{~h}$, while molybdenum additions increase the recrystallization temperature to as high as $1200^{\circ} \mathrm{C}$. This is indicated in Fig. 3 where the $0.4 \%$ Mo alloy shows a partial recrystallization $(\sim 10 \%)$ after being annealed at $1000^{\circ} \mathrm{C}$ and a complete recrystallization at $1200^{\circ} \mathrm{C}$. Second-phase particles are observed in Mo-containing

*Zinc was selected as an alloying element based on ab-initio calculations by D. M. Nicholson, Oak Ridge National Laboratory (ORNL). 
Table 2. Tensile properties of $\mathrm{NiAl}$ alloys

\begin{tabular}{|c|c|c|c|c|c|c|}
\hline \multirow{2}{*}{$\begin{array}{c}\text { Alloy } \\
\text { number }\end{array}$} & \multirow{2}{*}{$\begin{array}{l}\text { Concentration } \\
\text { of alloy } \\
\text { element } \\
(\text { at. } \%)\end{array}$} & \multicolumn{4}{|c|}{ Strength, MPa (ksi) } & \multirow{2}{*}{$\begin{array}{l}\text { Elongation } \\
(\%)\end{array}$} \\
\hline & & \multicolumn{2}{|c|}{ Yield } & \multicolumn{2}{|c|}{ Ultimate } & \\
\hline \multicolumn{7}{|c|}{ Room temperature } \\
\hline $\begin{array}{l}\text { NAL-31 } \\
\text { NAL-40 }\end{array}$ & $\begin{array}{l}\text { Base } \\
2.0 \mathrm{Fe}^{a}\end{array}$ & $\begin{array}{l}154 \\
254\end{array}$ & $\begin{array}{l}(22.4) \\
(36.9)\end{array}$ & $\begin{array}{l}229 \\
256\end{array}$ & $\begin{array}{l}(33.3) \\
(37.1)\end{array}$ & $\begin{array}{l}2.1 \\
0.3\end{array}$ \\
\hline NAL-64 & $2.0 \mathrm{Fe}^{c}$ & 196 & $(28.5)$ & 254 & $(36.8)$ & 1.3 \\
\hline NAL-41 & $5.0 \mathrm{Fe}^{a}$ & 73 & $(10.6)$ & 73 & (10.6) & 0 \\
\hline NAL-47 & $1.0 \mathrm{Ga}^{b}$ & 195 & $(28.3)$ & 269 & $(39.0)$ & 2.6 \\
\hline NAL-48 & $0.4 \mathrm{Ti}^{b}$ & 295 & $(42.8)$ & 352 & $(51.1)$ & 2.6 \\
\hline NAL-50 & $0.0025 Y^{C} \mathrm{C}$ & 165 & $(24.0)$ & 209 & $(30.3)$ & 1.5 \\
\hline \multicolumn{7}{|c|}{$600^{\circ} \mathrm{C}$} \\
\hline $\begin{array}{l}\text { NAL-31 } \\
\text { NAL-40 }\end{array}$ & $\begin{array}{l}\text { Base } \\
2.0 \mathrm{Fe}^{a}\end{array}$ & $\begin{array}{l}90 \\
94\end{array}$ & $\begin{array}{l}(13.0) \\
(13.7)\end{array}$ & $\begin{array}{l}165 \\
167\end{array}$ & $\begin{array}{l}(24.0) \\
(24.2)\end{array}$ & $\begin{array}{r}58.5 \\
6.7\end{array}$ \\
\hline NAL-47 & $1.0 \mathrm{Ga}^{b}$ & 118 & $(17.1)$ & 167 & $(24.3)$ & 86.0 \\
\hline NAL-48 & $0.4 \mathrm{Ti}^{b}$ & 178 & $(25.8)$ & 280 & $(40.6)$ & 35.9 \\
\hline NAL-50 & $0.0025 Y^{c}$ & 63 & $(9.1)$ & 111 & $(16.1)$ & 50.6 \\
\hline \multicolumn{7}{|c|}{$1000^{\circ} \mathrm{C}$} \\
\hline NAL-31 & Base & 39 & $(5.6)$ & 49 & (7.1) & 59.4 \\
\hline NAL-40 & 2.0 $\mathrm{Fe}^{a}$ & 54 & $(7.9)$ & 65 & (9.5) & 78.8 \\
\hline NAL. 47 & $1.0 \mathrm{Ga} b$ & 50 & $(7.3)$ & 53 & $(7.7)$ & 74.2 \\
\hline NAL-48 & $0.4 \mathrm{Ti}^{b}$ & 60 & $(8.7)$ & 70 & $(10.1)$ & 78.5 \\
\hline NAL-50 & $0.0025 Y^{c}$ & 35 & $(5.0)$ & 44 & $(6.4)$ & 72.6 \\
\hline
\end{tabular}

asubstitution for $\mathrm{Ni}$ atoms.

bSubstitution for $\mathrm{Al}$ atoms.

cSubstitution for both $\mathrm{Ni}$ and $\mathrm{Al}$ atoms. 
89-1197

101)

1,11

89-0597

$114 \quad 4$

Fig. 2. Optical micrograph of NAl alloys: (a) NAL +1 , $\mathrm{NiAl}+5 \% \mathrm{~F}$, annealed $1 \mathrm{~h}$ at 9()()$(\mathrm{C}$, and $(b) \mathrm{NAL}-4 \mathrm{x}$.

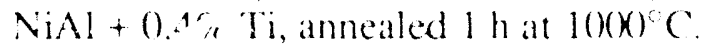


89-0067

$100 \mu \mathrm{m}$

(a)

89-0238

100 $\mu \mathrm{m}$

Fig. 3. Optical micrographs of NAL- $44(\mathrm{NiAl}+0.4 \% \mathrm{Mo})$ : (a) anneal $1 \mathrm{~h}$ at $1000^{\circ} \mathrm{C}$, partially recrystallized, and $(b)$ anneal $1 \mathrm{~h}$ at $1200^{\circ} \mathrm{C}$, completely recrystallized. 
alloys, indicating a low solubility of molybdenum in NiAl. Figure 4 shows that both coarse and fine precipitates are present in the $0.7 \%$ Mo alloy annealed for $1 \mathrm{~h}$ at $1200^{\circ} \mathrm{C}$ plus $1 \mathrm{~h}$ at $800^{\circ} \mathrm{C}$. Electron microprobe analysis of 0.2 and $0.7 \%$ Mo alloys revealed that the solubility of molybdenum in $\mathrm{NiAl}$ is around 0.1 at. \% and that the molybdenum-rich particles contain as high as $45 \%$ Mo (Table 3 ).

The effect of annealing treatment on room-temperature tensile properties of the $0.4 \%$ Mo alloy is shown in Table 4. The alloy showed a tensile ductility of 3.4 to $3.6 \%$ in the stressrelieved and partially recrystallized conditions. A complete recrystallization reduced the ductility to $1.3 \%$. This result indicates that Mo-containing NiAl alloys exhibit a better roomtemperature ductility when not completely recrystallized. Recrystallization also lowered the yield strength from 315 to $223 \mathrm{MPa}$. Figure 5 shows a mixed fracture mode for the $0.4 \%$ Mo alloy recrystallized at $1200^{\circ} \mathrm{C}$.

Table 5 summarizes the tensile properties of $\mathrm{NiAl}$ as a function of molybdenum concentration. All specimens (except for the binary NiAl alloy, NAL-31) were annealed for $1 \mathrm{~h}$ at 1000 to $1100^{\circ} \mathrm{C}$ to produce a partially recrystallized microstructure that gave the best tensile properties. The alloys containing 0.2 to $2.0 \%$ Mo showed a room-temperature tensile ductility of 3.3 to $4.4 \%$, which is significantly higher than that of the unalloyed $\mathrm{NiAl}(2.2 \%)$. All Mo-containing alloys are ductile at 600 and $1000^{\circ} \mathrm{C}$. Alloying with $0.2 \%$ Mo substantially increases the strength of $\mathrm{NiAl}$ at all the test temperatures. A further increase in molybdenum to 3 at. \% gives only a moderate increase in strength at elevated temperatures. Since the solubility of molybdenum is quite low $(\sim 0.1 \%)$, the beneficial effect is believed to come from second-phase particles that slow down the recrystallization process and stabilize a wrought structure. Note that the $0.7 \%$ Mo alloy (NAL-55) has a yield strength of $121 \mathrm{MPa}$ at $1000^{\circ} \mathrm{C}$, which is higher than that of unalloyed NiAl by a factor of three.

Figure 6 is a plot of the tensile properties as a function of temperature for the $0.4 \%$ Mo alloy (NAL-44), compared with those of the binary NiAl. The yield strength of both alloys decreases with temperature; however, NAL- 44 is stronger than NiAl by more than $100 \%$ at all test temperatures. Most importantly, NAL- 44 has a tensile ductility better than NiAl at ambient temperatures. The ductility of both alloys increases with temperature above $200^{\circ} \mathrm{C}$, and it increases sharply above $400^{\circ} \mathrm{C}$. The unalloyed $\mathrm{NiAl}$ has a higher ductility above $400^{\circ} \mathrm{C}$.

Since microalloying with boron suppresses intergranular fracture, 15,16 boron at a level of 30 wppm was added to the $0.4 \%$ Mo alloy. Table 6 compares the tensile properties of $0.4 \%$ Mo alloys with and without boron. The addition of boron appears to slightly increase the ductility and strength at room temperature and $200^{\circ} \mathrm{C}$, but it does not affect the tensile properties at higher temperatures. 


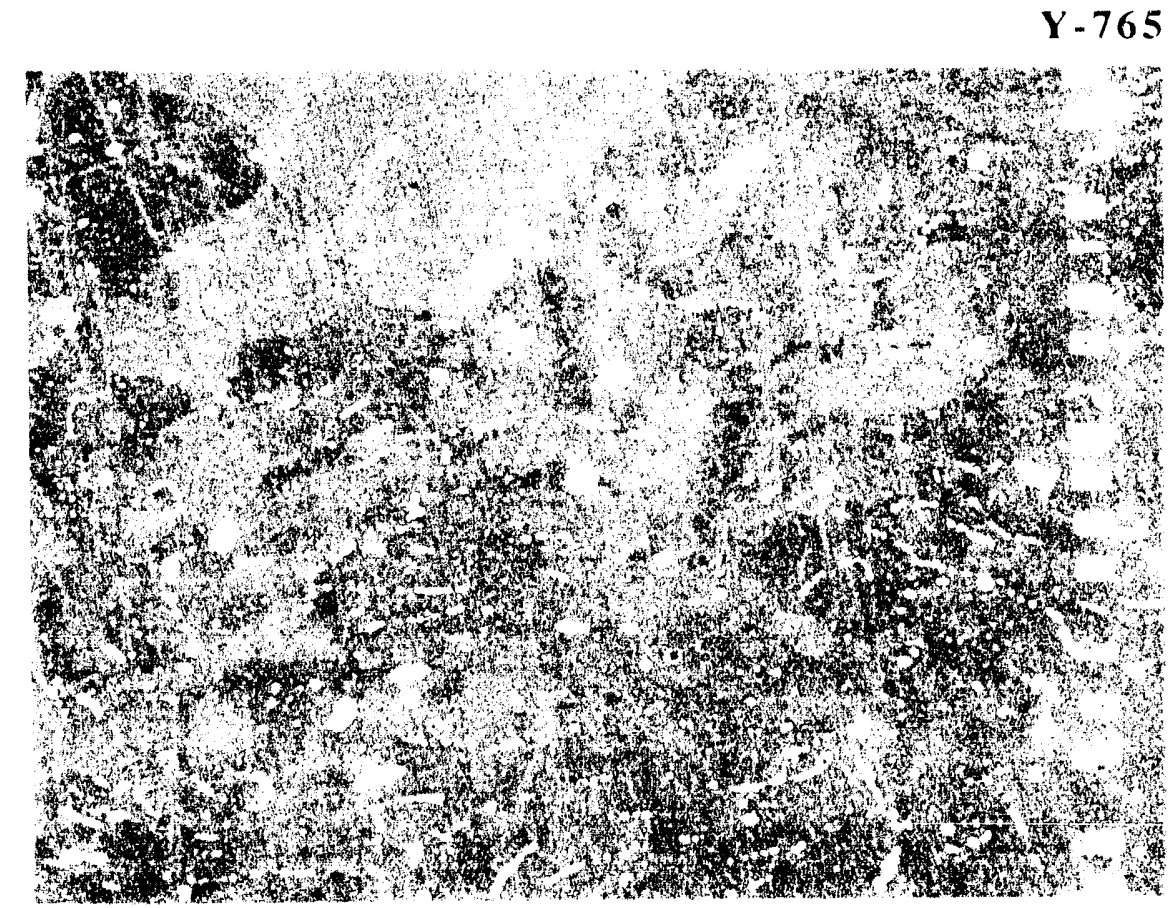

Fig. 4. Back-scattered electron micrograph showing the formation of molybdenum-rich particles in NAL - 55 ( NiAl + $(0.7 \%, \mathrm{Mo})$.

Table 3. Results of electron microprobe analyses of matrix and second-phase particles in NiAl alloys

\begin{tabular}{|c|c|c|c|c|c|c|c|}
\hline \multirow{2}{*}{$\begin{array}{l}\text { Alloy } \\
\text { number }\end{array}$} & \multirow{2}{*}{$\begin{array}{c}\text { Alloy } \\
\text { concentration } \\
\text { (at. \%) }\end{array}$} & \multicolumn{3}{|c|}{$\begin{array}{l}\text { Matrix } \\
\text { (at. \%) }\end{array}$} & \multicolumn{3}{|c|}{$\begin{array}{l}\text { Particle } \\
(\text { at. \%) }\end{array}$} \\
\hline & & $\mathrm{Al}$ & $\mathrm{Mo} / \mathrm{V}$ & $\mathrm{Nb} / \mathrm{Ta}$ & Al & $\mathrm{Mo} / \mathrm{V}$ & $\mathrm{Nb} / \mathrm{Ta}$ \\
\hline NAL -53 & $0.2 \mathrm{Mo}$ & 50.1 & 0.06 & & (I) 25 & 45 & \\
\hline NAL -5.5 & $0.7 \mathrm{Mo}$ & 48.1 & 0.12 & & (l) 25 & 45 & \\
\hline$N \wedge L-49$ & $0.4 \mathrm{~V}$ & 48.9 & 0.38 & & & & \\
\hline NAL. 59 & $1.5 \mathrm{Mo}+0.4 \mathrm{Nb}$ & 49.4 & 0.09 & $0 .(0)$ & $\begin{array}{l}\text { (I) } 10 \\
\text { (II) } 7\end{array}$ & $\begin{array}{l}75 \\
66\end{array}$ & $\begin{array}{r}8 \\
18\end{array}$ \\
\hline NAL.6? & $1.5 \mathrm{Mo}+1.0 \mathrm{Ta}$ & 49.9 & 0.09 & 0.26 & $\begin{array}{l}\text { (I) } 12 \\
\text { (II) } 32\end{array}$ & $\begin{array}{r}50 \\
6\end{array}$ & $\begin{array}{l}20 \\
33\end{array}$ \\
\hline
\end{tabular}


Table 4. Effect of heat treatment on room-temperature tensile properties of NAL- $44(\mathrm{NiAl}+0.4 \% \mathrm{Mo})$

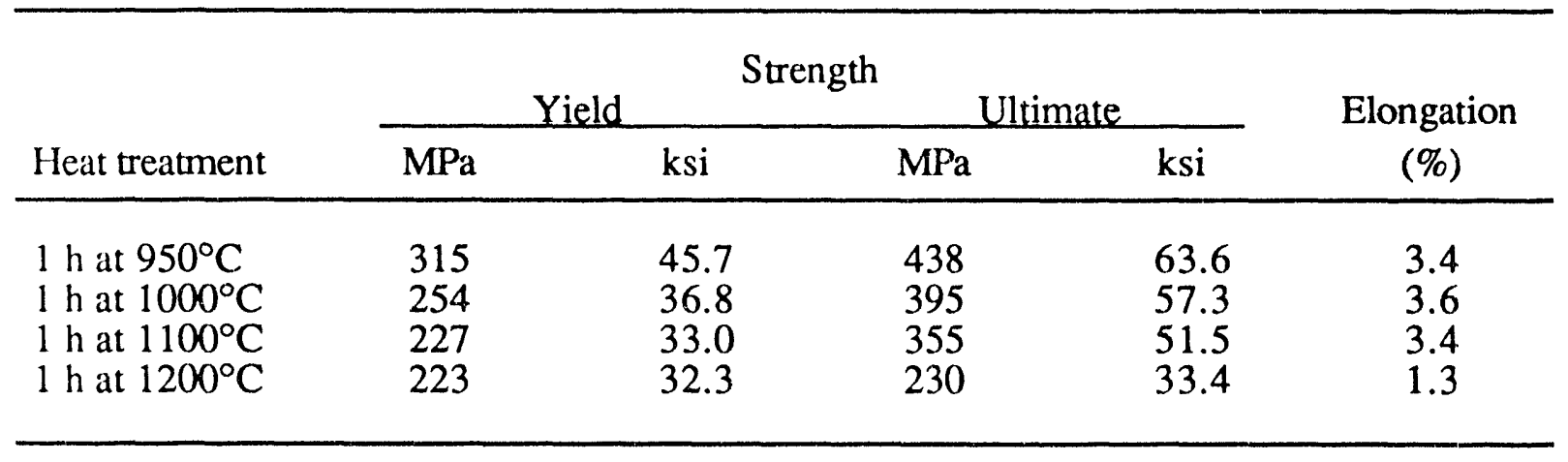

M21019

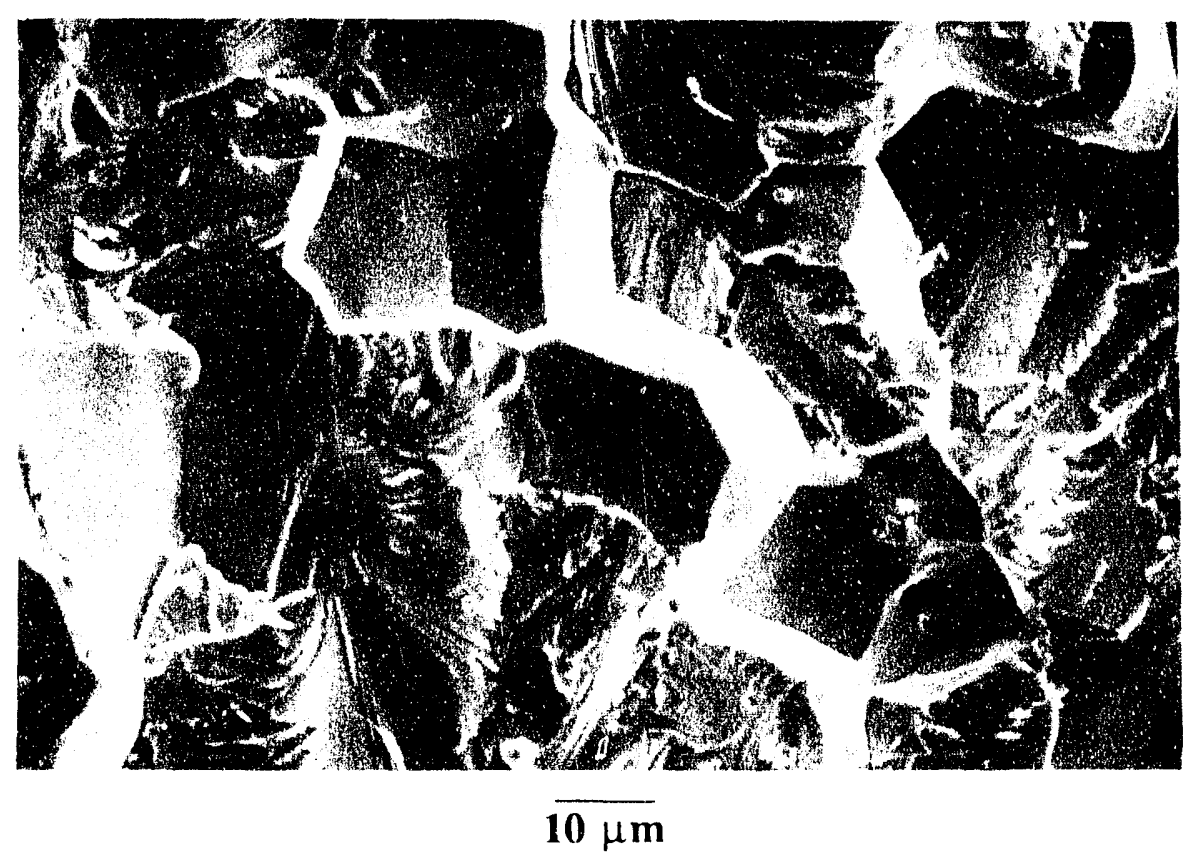

Fig. 5. SEM fractograph of NAL-44 (NiAl + 0.4\% Mo) annealed $1 \mathrm{~h}$ at $1200^{\circ} \mathrm{C}$, showing a mixed fracture mode. 

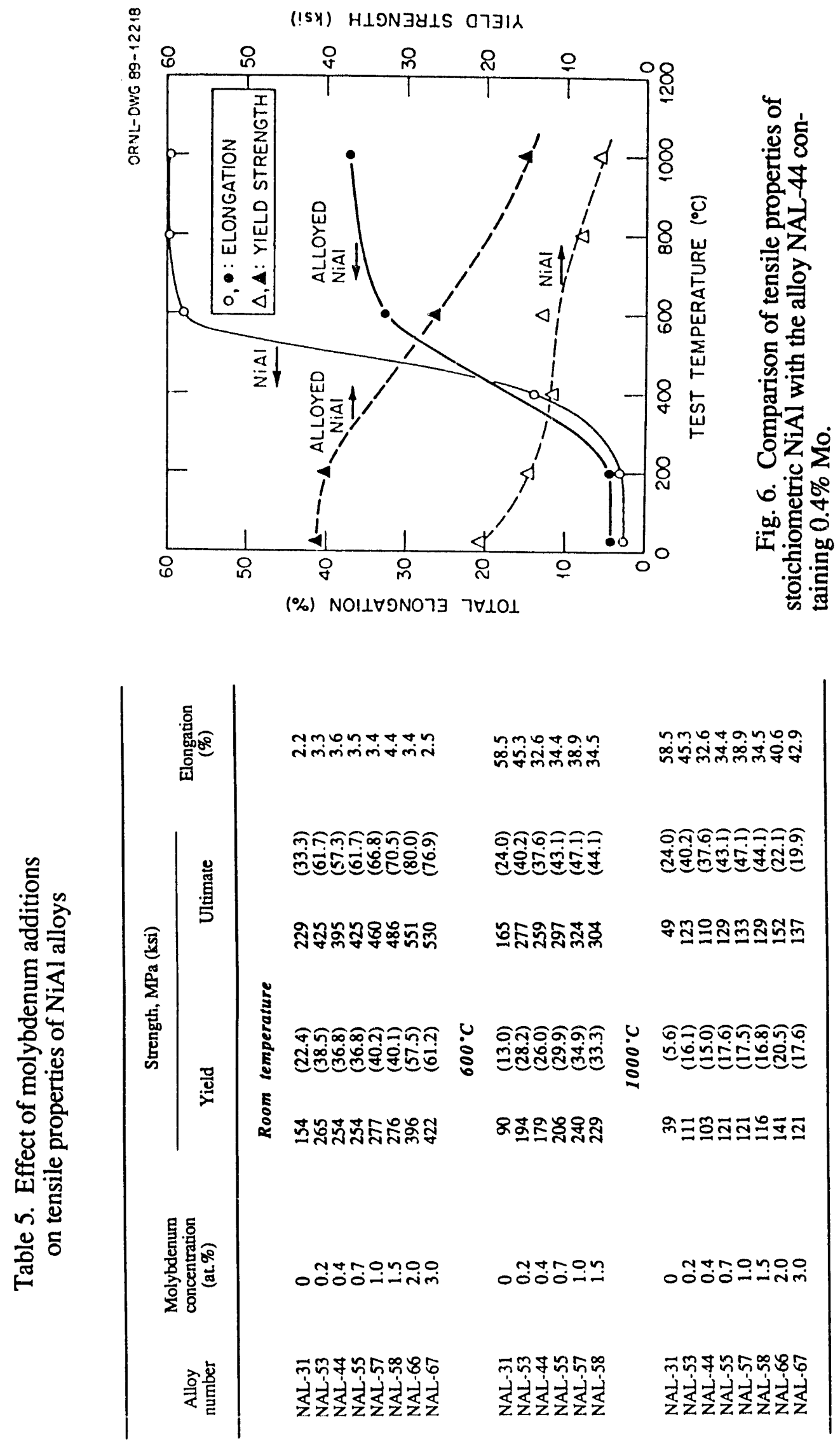
Table 6. Effect of boron doping on tensile properties of $\mathrm{NiAl}$ containing 0.4 at. \% Mo

\begin{tabular}{|c|c|c|c|c|c|c|}
\hline \multirow{2}{*}{$\begin{array}{c}\text { Alloy } \\
\text { number }\end{array}$} & \multirow{2}{*}{$\begin{array}{c}\text { Boron } \\
\text { concentration } \\
\text { (wppm) }\end{array}$} & \multicolumn{4}{|c|}{ Strength, MPa (ksi) } & \multirow{2}{*}{$\begin{array}{c}\text { Elongation } \\
(\%)\end{array}$} \\
\hline & & \multicolumn{2}{|c|}{ Yield } & \multicolumn{2}{|c|}{ Ultimate } & \\
\hline & & Roon & temper & & & \\
\hline \multirow[t]{2}{*}{$\begin{array}{l}\text { NAL-44 } \\
\text { NAL-55 }\end{array}$} & $\begin{array}{r}0 \\
30\end{array}$ & $\begin{array}{l}254 \\
283\end{array}$ & $\begin{array}{l}(36.8) \\
(41.1)\end{array}$ & $\begin{array}{l}395 \\
461\end{array}$ & $\begin{array}{l}(57.3) \\
(66.9)\end{array}$ & $\begin{array}{l}3.6 \\
4.2\end{array}$ \\
\hline & & & $200^{\circ} \mathrm{C}$ & & & \\
\hline \multirow[t]{2}{*}{$\begin{array}{l}\text { NAL-44 } \\
\text { NAL-45 }\end{array}$} & $\begin{array}{r}0 \\
30\end{array}$ & $\begin{array}{l}249 \\
274\end{array}$ & $\begin{array}{l}(36.2) \\
(39.8)\end{array}$ & $\begin{array}{l}371 \\
408\end{array}$ & $\begin{array}{l}(53.9) \\
(59.2)\end{array}$ & $\begin{array}{l}3.6 \\
4.3\end{array}$ \\
\hline & & & $600^{\circ} \mathrm{C}$ & & & \\
\hline \multirow[t]{2}{*}{$\begin{array}{l}\text { NAL-44 } \\
\text { NAL-46 }\end{array}$} & $\begin{array}{r}0 \\
30\end{array}$ & $\begin{array}{l}179 \\
182\end{array}$ & $\begin{array}{l}(26.0) \\
(26.4)\end{array}$ & $\begin{array}{l}256 \\
263\end{array}$ & $\begin{array}{l}(37.6) \\
(38.2)\end{array}$ & $\begin{array}{l}32.6 \\
32.6\end{array}$ \\
\hline & & & $1000^{\circ} \mathrm{C}$ & & & \\
\hline $\begin{array}{l}\text { NAL-44 } \\
\text { NAL-45 }\end{array}$ & $\begin{array}{r}0 \\
30\end{array}$ & $\begin{array}{l}103 \\
102\end{array}$ & $\begin{array}{l}(15.0) \\
(14.8)\end{array}$ & $\begin{array}{l}110 \\
112\end{array}$ & $\begin{array}{l}(15.9) \\
(16.3)\end{array}$ & $\begin{array}{l}31.5 \\
36.9\end{array}$ \\
\hline
\end{tabular}

Table 7 compares the tensile properties of $\mathrm{NiAl}$ alloys containing $0.4 \% \mathrm{Mo}, \mathrm{W}$, or $\mathrm{V}$ tested at room temperature and $1000^{\circ} \mathrm{C}$. Tungsten is most effective in strengthening $\mathrm{NiAl}$, but it appears not to affect the ductility at room temperature. Vanadium is less effective in strengthening $\mathrm{NiAl}$ at $1000^{\circ} \mathrm{C}$ and significantly lowers the room-temperature ductility. Alloying with vanadium, however, improves the creep properties of $\mathrm{NiAl}$, as will be described in Sect. 8.

Unlike the molybdenum- and tungsten-containing alloys, the vanadium-containing alloy is essentially single phase in structure. The electron microprobe analyses in Table 3 showed that $\mathrm{NiAl}$ can dissolve more than $0.4 \% \mathrm{~V}$. Hence, the strengthening effect of vanadium in NiAl-49 must come from solid-solution hardening. Darolia et al. ${ }^{32}$ recently reported that the addition of vanadium changes the slip behavior but does not impart ductility to $\mathrm{NiAl}$. 
Table 7. Effect of 0.4 at. \% vanadium, molybdenum, or tungsten on tensile properties of NiAl

\begin{tabular}{|c|c|c|c|c|c|c|}
\hline \multirow{2}{*}{$\begin{array}{c}\text { Alloy } \\
\text { number }\end{array}$} & \multirow{2}{*}{$\begin{array}{l}\text { Alloying } \\
\text { element }\end{array}$} & \multicolumn{4}{|c|}{ Strength, MPa (ksi) } & \multirow{2}{*}{$\begin{array}{l}\text { Elongation } \\
(\%)\end{array}$} \\
\hline & & \multicolumn{2}{|c|}{ Yield } & \multicolumn{2}{|c|}{ Ultimate } & \\
\hline \multirow{3}{*}{$\begin{array}{l}\text { NAL-31 } \\
\text { NAL-44 } \\
\text { NAL-51 } \\
\text { NAL-49 }\end{array}$} & & Room & tempera & & & \\
\hline & $\begin{array}{l}0 \\
\text { Mo } \\
\text { W } \\
\text { V }\end{array}$ & $\begin{array}{l}154 \\
254 \\
323 \\
238\end{array}$ & $\begin{array}{l}(22.4) \\
(36.8) \\
(46.9) \\
(34.5)\end{array}$ & $\begin{array}{l}229 \\
395 \\
449 \\
274\end{array}$ & $\begin{array}{l}(33.3) \\
(57.3) \\
(65.1) \\
(39.8)\end{array}$ & $\begin{array}{l}2.2 \\
3.6 \\
2.5 \\
1.1\end{array}$ \\
\hline & \multicolumn{5}{|c|}{$1000^{\circ} \mathrm{C}$} & \\
\hline $\begin{array}{l}\text { NAL-31 } \\
\text { NAL-44 } \\
\text { NAL-51 } \\
\text { NAL-49 }\end{array}$ & $\begin{array}{l}0 \\
\text { Mo } \\
\text { W } \\
\text { V }\end{array}$ & $\begin{array}{r}37 \\
103 \\
118 \\
64\end{array}$ & $\begin{array}{r}(5.6) \\
(15.0) \\
(17.1) \\
(9.3)\end{array}$ & $\begin{array}{r}49 \\
110 \\
129 \\
72\end{array}$ & $\begin{array}{c}(7.1) \\
(15.9) \\
(18.7) \\
(10.5)\end{array}$ & $\begin{array}{c}59.4 \\
31.5 \\
32.1 \\
69.0\end{array}$ \\
\hline
\end{tabular}

\section{INITIAL ALLOY DEVELOPMENT OF NiAI ALLOYS}

The foregoing section indicates that molybdenum is quite effective in improving both the room-temperature ductility and high-temperature strength. As a result, the NiAl alloy containing 1.5 at. \% Mo (NAL-58) was chosen as a base for further alloying. The alloying elements $\mathrm{Nb}, \mathrm{Ta}$, and $\mathrm{V}$ were selected for addition to NAL-58, since they are effective in improving creep resistance. ${ }^{33}$ Table 8 lists the alloy compositions based on NAL-58. The alloys were prepared and fabricated in the same way as the earlier alloys, except that an extrusion temperature of 1050 , instead of $900^{\circ} \mathrm{C}$, was necessary to fabricate a few of the stronger alloys such as NAL- 60 . The yield strength of NAL-58 is substantially increased by additions of $\mathrm{Nb}, \mathrm{Ta}$, and $\mathrm{V}$; however, the increase in strength results in a decrease in the tensile ductility at room temperature. The alloys essentially showed a mixed fracture mode, with transgranular cleavage as the major fracture mode at room temperature (Fig. 7). At $1000^{\circ} \mathrm{C}$, niobium is most effective in strengthening and causes no reduction in ductility. The alloy NAL- 60 containing $1 \% \mathrm{Nb}$ has a yield strength five times higher than that of unalloyed NiAl (NAL-31) at $1000^{\circ} \mathrm{C}$. 
Table 8. Tensile properties of complex $\mathrm{NiAl}$ alloys

\begin{tabular}{|c|c|c|c|c|c|c|}
\hline \multirow{2}{*}{$\begin{array}{l}\text { Alloy } \\
\text { number }\end{array}$} & \multirow{2}{*}{$\begin{array}{l}\text { Alloy } \\
\text { concentration } \\
\text { (at. \%) }\end{array}$} & \multicolumn{4}{|c|}{ Strength, $\mathrm{MPa}(\mathrm{ksi})$} & \multirow{2}{*}{$\begin{array}{c}\text { Elongation } \\
(\%)\end{array}$} \\
\hline & & \multicolumn{2}{|c|}{ Yield } & \multicolumn{2}{|c|}{ Ultimate } & \\
\hline & & Room & temperature & & & \\
\hline $\begin{array}{l}\text { NAL-31 } \\
\text { NAL-58 } \\
\text { NAL-59 } \\
\text { NAL-60 } \\
\text { NAL-61 } \\
\text { NAL-62 } \\
\text { NAL-72 } \\
\text { NAL-73 }\end{array}$ & $\begin{array}{l}0 \\
1.5 \mathrm{Mo} \\
1.5 \mathrm{Mo}+0.4 \mathrm{Nb} \\
1.5 \mathrm{Mo}+1.0 \mathrm{Nb} \\
1.5 \mathrm{Mo}+0.4 \mathrm{Ta} \\
1.5 \mathrm{Mo}+1.0 \mathrm{Ta} \\
1.5 \mathrm{Mo}+0.4 \mathrm{~V} \\
1.5 \mathrm{Mo}+1.0 \mathrm{~V}\end{array}$ & $\begin{array}{l}154 \\
276 \\
325 \\
402 \\
328 \\
388 \\
340 \\
338\end{array}$ & $\begin{array}{l}(22.4) \\
(40.1) \\
(47.2) \\
(58.3) \\
(47.6) \\
(56.3) \\
(49.3) \\
(49.1)\end{array}$ & $\begin{array}{l}229 \\
486 \\
466 \\
431 \\
472 \\
413 \\
513 \\
494\end{array}$ & $\begin{array}{l}(33.3) \\
(70.5) \\
(67.7) \\
(62.6) \\
(68.5) \\
(59.9) \\
(74.4) \\
(71.7)\end{array}$ & $\begin{array}{l}2.2 \\
4.4 \\
2.8 \\
1.0 \\
2.9 \\
1.3 \\
3.4 \\
2.8\end{array}$ \\
\hline \multicolumn{7}{|c|}{$1000^{\circ} \mathrm{C}$} \\
\hline $\begin{array}{l}\text { NAL-31 } \\
\text { NAL-58 } \\
\text { NAL-59 } \\
\text { NAL-60 } \\
\text { NAL-61 } \\
\text { NAL-62 } \\
\text { NAL-72 } \\
\text { NAL-73 }\end{array}$ & $\begin{array}{l}0 \\
1.5 \mathrm{Mo} \\
1.5 \mathrm{Mo}+0.4 \mathrm{Nb} \\
1.5 \mathrm{Mo}+1.0 \mathrm{Nb} \\
1.5 \mathrm{Mo}+0.4 \mathrm{Ta} \\
1.5 \mathrm{Mo}+1.0 \mathrm{Ta} \\
1.5 \mathrm{Mo}+0.4 \mathrm{~V} \\
1.5 \mathrm{Mo}+1.0 \mathrm{~V}\end{array}$ & $\begin{array}{r}39 \\
116 \\
166 \\
195 \\
134 \\
163 \\
\\
143\end{array}$ & $\begin{array}{l}(5.6) \\
(16.8) \\
(24.1) \\
(28.3) \\
(19.4) \\
(23.6) \\
(20.8)\end{array}$ & $\begin{array}{r}49 \\
129 \\
181 \\
225 \\
146 \\
188 \\
\\
155\end{array}$ & $\begin{array}{l}(7.1) \\
(18.7) \\
(26.2) \\
(32.6) \\
(21.2) \\
(27.3) \\
(22.5)\end{array}$ & $\begin{array}{l}59.4 \\
43.8 \\
35.6 \\
40.5 \\
36.8 \\
27.4 \\
41.6\end{array}$ \\
\hline
\end{tabular}

M21020

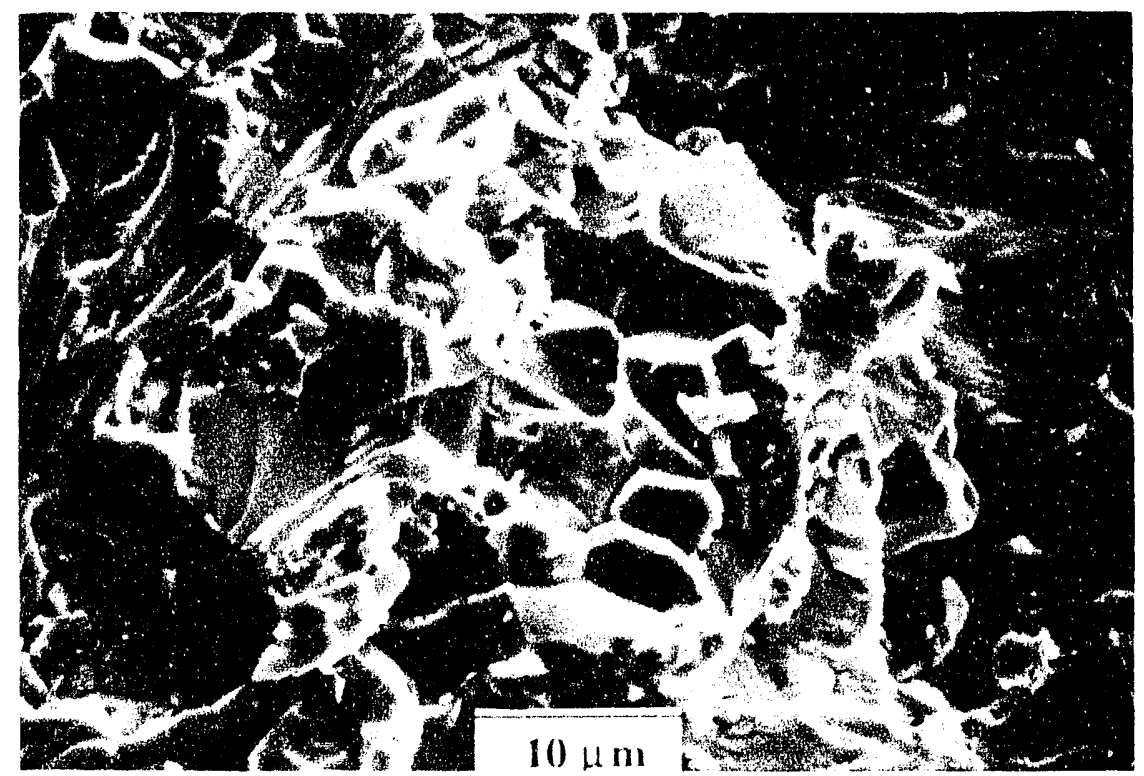

Fig. 7. SEM fractograph of NAL-61 (NiAl + 1.5\% Mo + $0.4 \% \mathrm{Ta}$, at. $\%$ ) fractured at room temperature. 
Figure 8 shows the grain structure and second-phase particles in NAL-59 after annealing for $1 \mathrm{~h}$ at $1300^{\circ} \mathrm{C}$. Both coarse and fine particles are observed, and the fine particles are distributed uniformly, while the coarse particles tend to line up and form stringers. The compositions of the matrix and particle phases in NAL-59 containing molybdenum and niobium, and in NAL- 62 containing molybdenum and tantalum, were determined by electron microprobe analyses. The results are shown in Table 3. NiAl dissolves about $0.1 \% \mathrm{Mo}$ and $0.26 \% \mathrm{Ta}$, and practically no niobium. Two types of particles are observed in the alloys. Particle (I) contains a higher level of molybdenum (50 to 75\%), and particle (II) contains a higher level of $\mathrm{Nb} / \mathrm{Ta}$ (18 to $33 \%$ ). Note that alloying with niobium or tantalum does not affect the solubility of Mo, which is about $0.1 \%$ in NiAl.

\section{TEM STUDY OF NiAl ALLOYS}

Three NiAl alloys containing molybdenum, niobium, and tantalum were examined by transmission electron microscopy (TEM). The alloys are NAL-55 containing $0.7 \%$ Mo, NAL-59 containing $1.5 \% \mathrm{Mo}$ and $0.4 \% \mathrm{Nb}$, and NAL-61 containing $1.5 \% \mathrm{Mo}$ and $0.4 \% \mathrm{Ta}$. Alloy specimens were annealed for $1 \mathrm{~h}$ at 1200 to $1300^{\circ} \mathrm{C}$ and then deformed in tension at room temperature. TEM disks were sectioned from the tensile specimens and then electropolished in a solution of $10 \%$ perchloric acid and $90 \%$ methanol at a temperature of $-30^{\circ} \mathrm{C}$ and at $22 \mathrm{~V}$. TEM was performed on Philips CM12 and CM30 microscopes. A number of different precipitates formed with a range in sizes. Preliminary diffraction information indicates that most of these precipitates retain the bec or B2 structure with a small unit cell. The lattice parameters of the particles are around $0.31 \mathrm{~nm}$, as compared to the B2 matrix with a lattice parameter of about $0.283 \mathrm{~nm}$. The small precipitates ranged in size from 0.25 to $1 \mu \mathrm{m}$. It is expected that the small precipitates pin dislocations and contribute to strengthening of these alloys. Table 9 presents the compositional analyses of matrix and precipitate phases, as determined by TEM using energy dispersive spectroscopy (EDS). The analyses were usually made on precipitates that protruded into the electropolishing hole and thereby minimized any matrix contributions. The compositional analyses from TEM/EDS are reasonably consistent with those from electron microprobe analyses in Table 3. Some small particles containing lead were detected in the alloy NAL-61.

Figures 9 and 10 show TEM images of NAL-55 and NAL-61, respectively. The specimen in Fig. 9 was strained $1.3 \%$ at room temperature, while the specimen in Fig. 2 was strained $2.9 \%$. Many dislocation loops are present throughout the microstructure of all the 
(a)

$100 \mu \mathrm{m}$

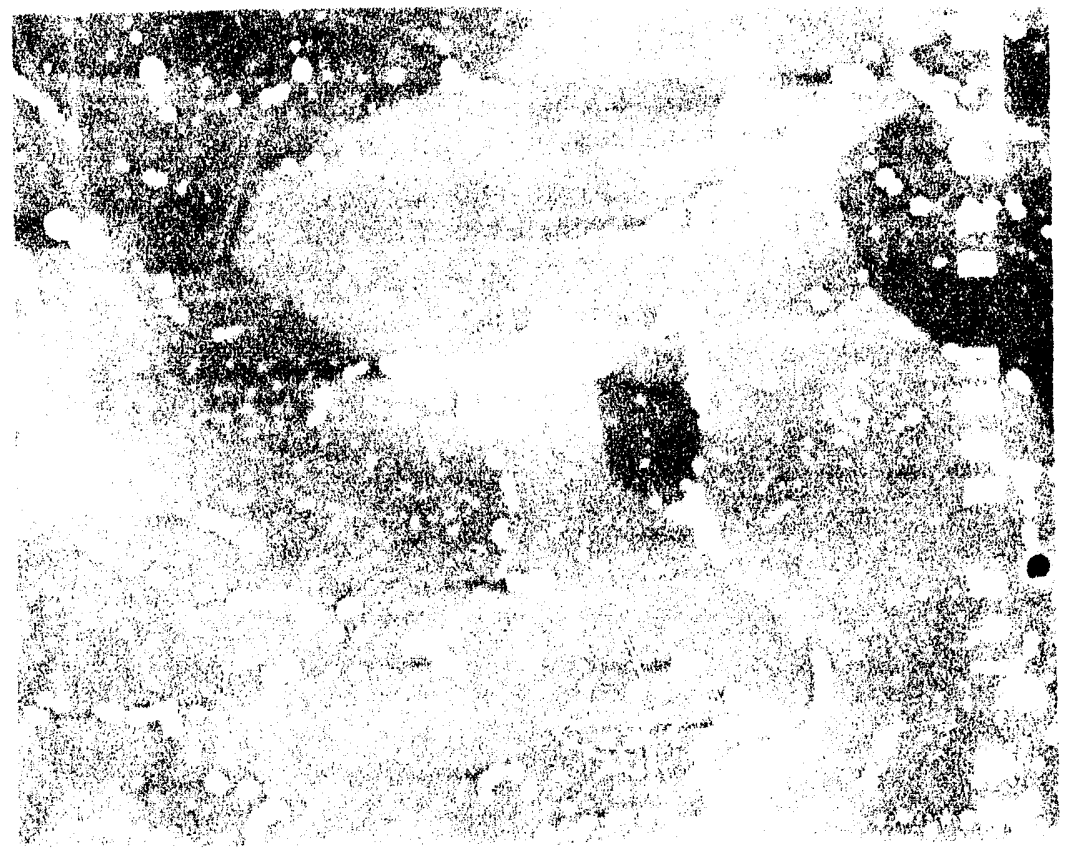

(b)

$10 \mu \mathrm{m}$

Fig. 8. Microstructure of NAL-59 (NiAl + 1.5\% Mo + $0.4 \%$ No, at. $\%$ ) anincalcd for 1 h at $1300^{\circ} \mathrm{C}$ : (a) optical micrograph and $(b)$ back-scattered electron micrograph. 
Table 9. TEM compositional analysis by EDS

\begin{tabular}{|c|c|c|c|c|}
\hline \multirow{2}{*}{$\begin{array}{l}\text { Alloy number } \\
\text { NAL-55a }\end{array}$} & \multicolumn{4}{|c|}{ Composition of phases (at. \%) } \\
\hline & Aluminum & Nickel & Molybdenum & \\
\hline $\begin{array}{l}\text { PPT (I) } \\
\text { PPT (II) } \\
\text { Matrix } \\
\text { Nominal }\end{array}$ & $\begin{array}{l}26 \\
10 \\
49 \\
49.65\end{array}$ & $\begin{array}{l}27 \\
5 \\
51 \\
49.65\end{array}$ & $\begin{array}{c}47 \\
85 \\
- \\
0.7\end{array}$ & \\
\hline NAL-59 $b$ & Aluminum & Nickel & Molybdenum & Niobium \\
\hline $\begin{array}{l}\text { PPT (I) } \\
\text { PPT (II) } \\
\text { PPT (III) } \\
\text { Matrix } \\
\text { Nominal }\end{array}$ & $\begin{array}{l}24 \\
30 \\
38 \\
49.5 \\
49.05\end{array}$ & $\begin{array}{l}11 \\
15 \\
34 \\
50.5 \\
49.05\end{array}$ & $\begin{array}{l}57 \\
32 \\
24 \\
-- \\
1.5\end{array}$ & $\begin{array}{r}8 \\
23 \\
4 \\
- \\
0.4\end{array}$ \\
\hline NAL- $61 c$ & Aluminum & Nickel & Molvbdenum & Tantalum \\
\hline $\begin{array}{l}\text { PPT (I) } \\
\text { Matrix } \\
\text { Nominal }\end{array}$ & $\begin{array}{l}8 \\
49 \\
49.05\end{array}$ & $\begin{array}{l}7 \\
51 \\
49.05\end{array}$ & $\begin{array}{l}70 \\
-- \\
1.5\end{array}$ & $\begin{array}{l}15 \\
-- \\
0.4\end{array}$ \\
\hline
\end{tabular}

${ }^{a} \mathrm{Ni}-50 \mathrm{Al}-0.4 \mathrm{Mo}$ (at. \%) annealed for $1 \mathrm{~h}$ at $1200^{\circ} \mathrm{C}$.

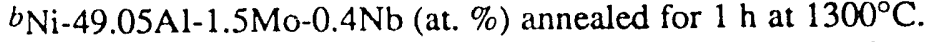

${ }^{c} \mathrm{Ni}-49.05 \mathrm{Al}-1.5 \mathrm{Mo}-0.4 \mathrm{Ta}$ (at. \%) annealed for $1 \mathrm{~h}$ at $1200^{\circ} \mathrm{C}$.

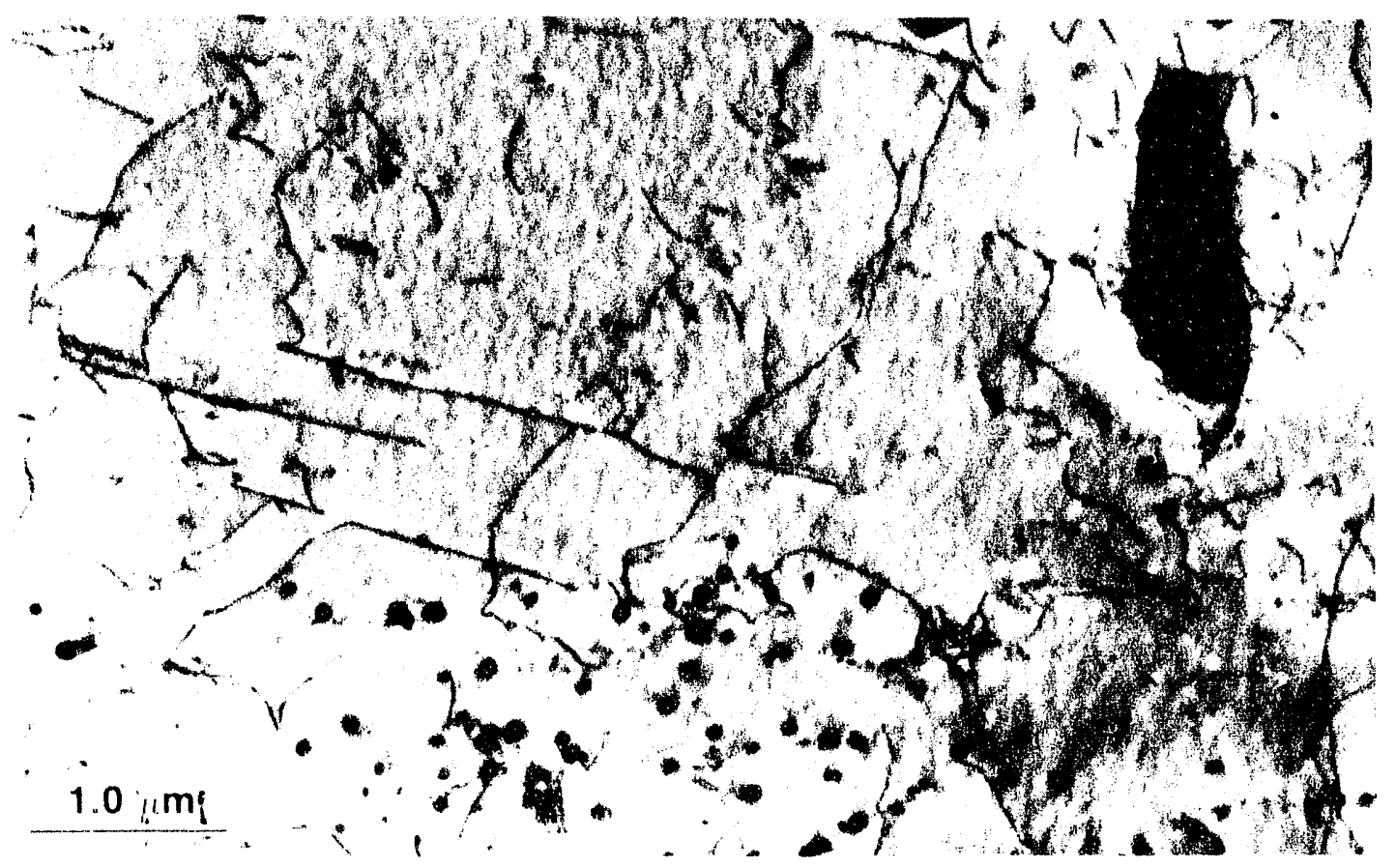

Fig. 9. TEMA micrograph of alloy NAL-55 after an anneal of $1 \mathrm{~h}$ at $1200^{\circ} \mathrm{C}$ and a strain of $1.3 \%$ showing precipitate and dislocation distribution. 


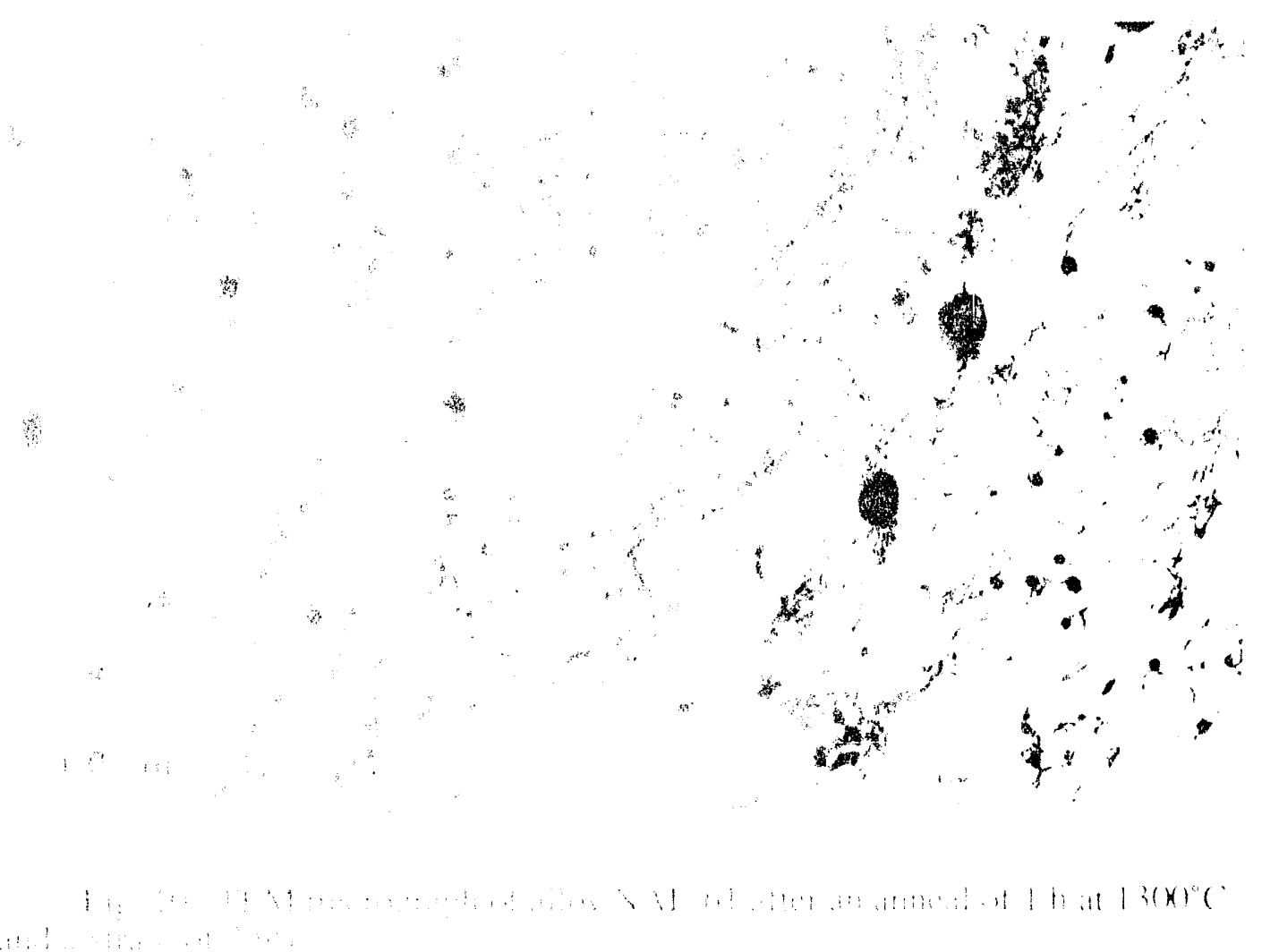

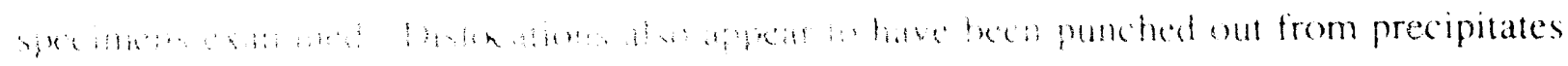

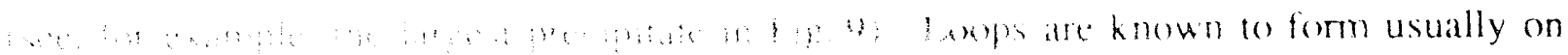

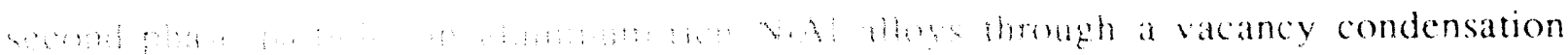

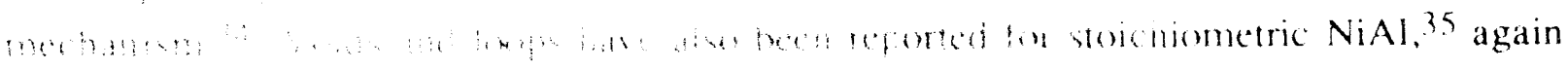

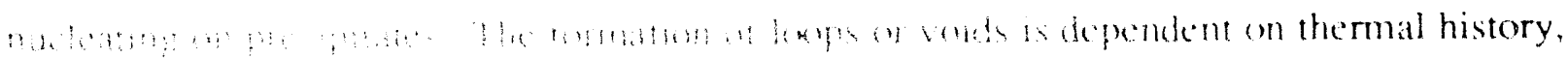

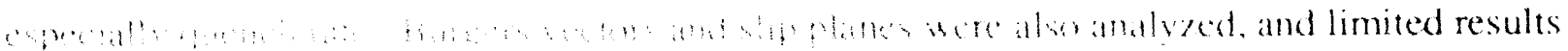

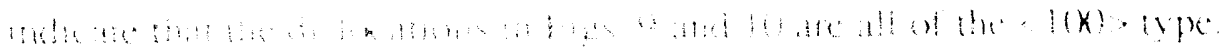

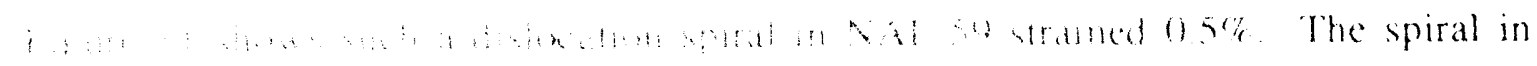

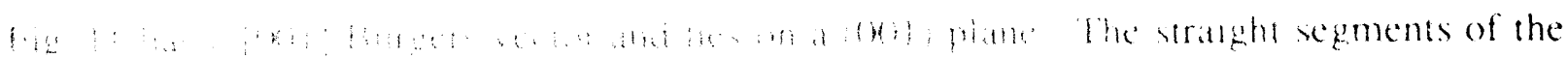

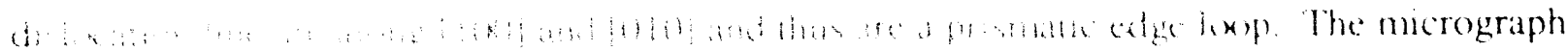

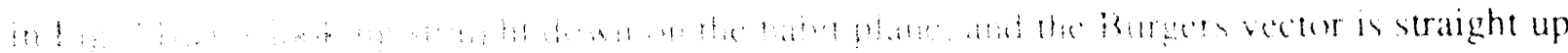

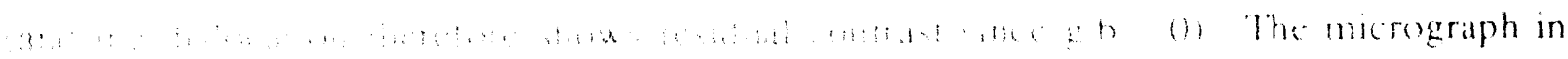

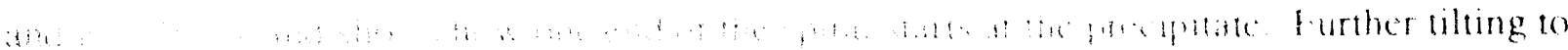

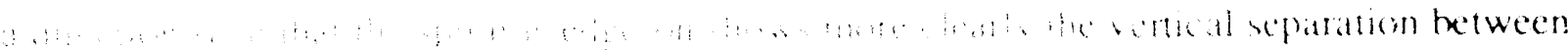

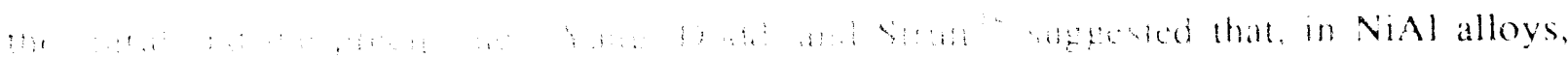

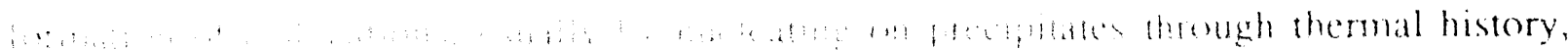

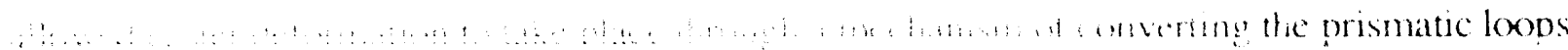




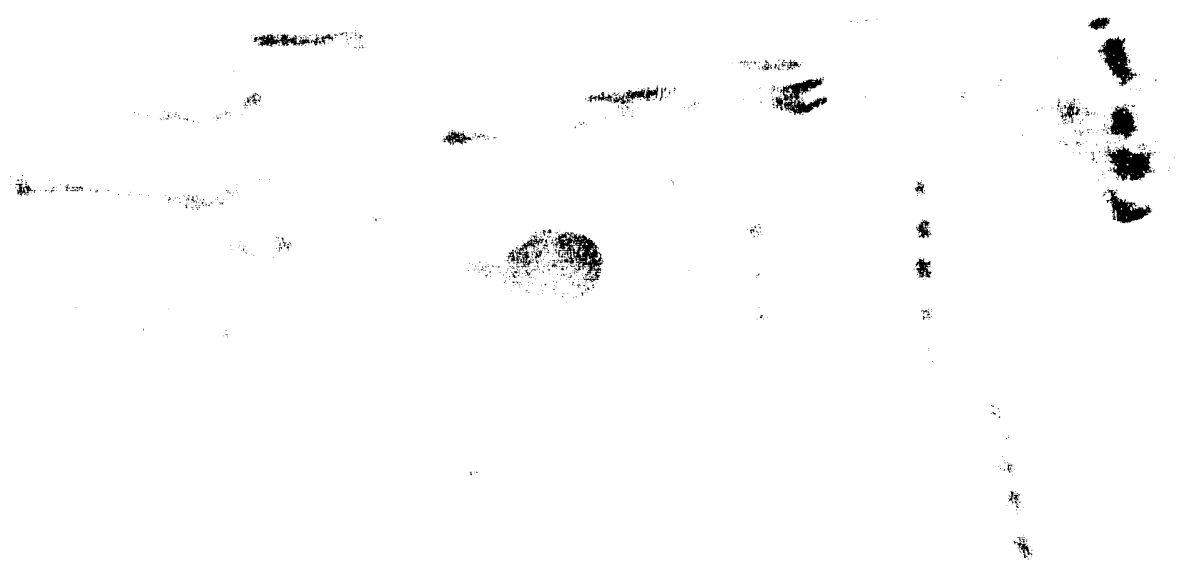

$100 \mathrm{~nm}$

1,1
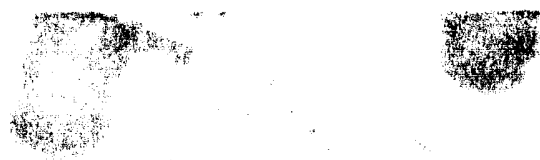

-9

$100 \mathrm{~nm}$

$\therefore$ a th

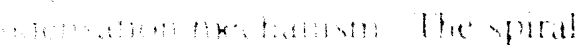

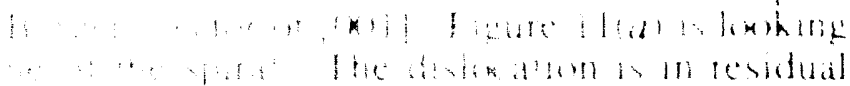

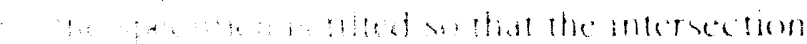

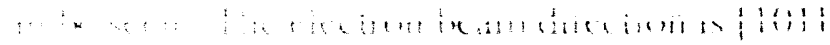




\section{CREEP PROPERTIES OF NiAI ALLOYS}

Creep properties of $\mathrm{NiAl}$ alloys were determined at applied stresses of 69 and $138 \mathrm{MPa}$ at $816^{\circ} \mathrm{C}\left(1500^{\circ} \mathrm{F}\right)$ in air. All buttonhead specimens with a dimension of $3.18 \mathrm{~mm}$ diam by $17.8 \mathrm{~mm}$ long were heat treated to produce a partially or fully recrystallized structure prior to creep testing. The creep strain was measured by a dial gage, and the rupture elongation was determined at room temperature. The applied stress was calculated from the original cross section of alloy specimens, and no correction was made on reduction of area during creep testing.

Table 10 summarizes the creep results of ternary $\mathrm{NiAl}$ alloys tested at $69 \mathrm{MPa}$ and $816^{\circ} \mathrm{C}$. All alloys were extremely ductile, with a rupture elongation over $60 \%$. The binary $\mathrm{NiAl}$ (NAL-31) is extremely weak in creep, and the alloy ruptured in $0.1 \mathrm{~min}$. Alloying with $2 \% \mathrm{Fe}$ gives a small increase in the rupture life. Among the ternary elements added, vanadium is most effective in extending the rupture life and reducing the creep rate of NiAl. Tungsten ranks second in improving creep resistance.

Creep properties obtained at $138 \mathrm{MPa}$ and $816^{\circ} \mathrm{C}$ are summarized in Table 11 for Mo-modified NiAl alloys with and without additions of niobium, tantalum, and vanadium. Additions of molybdenum give a moderate increase in the rupture life of NiAl. The addition of niobium and tantalum to $1.5 \%$ Mo alloys is most effective in improving the creep properties. As a matter of fact, alloying with $1 \%$ Ta extends the rupture life by four orders of magnitude. This result clearly indicates that the creep properties of $\mathrm{NiAl}$ alloys can be dramatically improved by alloy additions. Because of the low solubility of niobium and tantalum in $\mathrm{NiAl}$ (see Tables 3 and 9), the benefit of these elements mainly comes from a particle-strengthening effect. The pinning of mobile dislocations by fine niobium- or tantalum-rich precipitates may be the mechanism for reducing the creep rate in $\mathrm{NiAl}$ alloys.

\section{OXIDATION PROPERTIES}

Oxidation properties of NiAl alloys containing molybdenum (NAL-58) and molybdenum combined with $\mathrm{Nb}$ (NAL-59), Ta (NAL-61), and V (NAL-72) were determined by exposure to air for up to $5(0)$ h at 800 and 1000$)^{\circ} \mathrm{C}$, respectively. Disk specimens were first heat-tueated for $1 \mathrm{~h}$ at $1100^{\circ} \mathrm{C}$ plus $1 \mathrm{~h}$ at $800^{\circ} \mathrm{C}$ prior to air exposure. The alloy specimens were periodically removed from furnaces and cooled to room temperature for weight measurements. 
Table 10. Creep properties of $\mathrm{NiAl}$ alloys tested at $68.9 \mathrm{MPa}$ $(10 \mathrm{ksi})$ and $816^{\circ} \mathrm{C}\left(1500^{\circ} \mathrm{F}\right)$ in air

\begin{tabular}{ccccc}
\hline $\begin{array}{c}\text { Alloy } \\
\text { number }\end{array}$ & $\begin{array}{c}\text { Alloy concentration } \\
(\text { at. \%) }\end{array}$ & $\begin{array}{c}\text { Rupture life } \\
(\mathrm{h})\end{array}$ & $\begin{array}{c}\text { Minimum creep rate } \\
(\% / \mathrm{h})\end{array}$ & $\begin{array}{c}\text { Rupture } \\
\text { elongation } \\
(\%)\end{array}$ \\
\hline NAL-31 & 0 & 0.1 & 257.0 & 63.0 \\
NAL-64 & $2 \mathrm{Fe}$ & 0.5 & 57.0 & 75.3 \\
NAL-44 & $0.4 \mathrm{Mo}$ & 22.0 & 0.90 & 77.0 \\
NAL-58 & $1.5 \mathrm{Mo}$ & 41.3 & 0.57 & 64.3 \\
NAL-51 & $0.4 \mathrm{~W}$ & 57.1 & 0.43 & 52.9 \\
NAL-49 & $0.4 \mathrm{~V}$ & 202.0 & 0.042 & 62.0 \\
\hline
\end{tabular}

Table 11. Creep properties of $\mathrm{NiAl}$ alloys tested at $138 \mathrm{MPa}(20 \mathrm{ksi})$ and $816^{\circ} \mathrm{C}\left(1500^{\circ} \mathrm{F}\right)$

\begin{tabular}{|c|c|c|c|c|}
\hline $\begin{array}{c}\text { Alloy } \\
\text { number }\end{array}$ & $\begin{array}{l}\text { Alloy concentration } \\
(\text { (at. \%) }\end{array}$ & $\underset{\text { (h) }}{\text { Rupture life }}$ & $\begin{array}{c}\text { Minimum creep rate } \\
(\% / \mathrm{h})\end{array}$ & $\begin{array}{l}\text { Rupture } \\
\text { elongation } \\
(\%)\end{array}$ \\
\hline NAL-31 & 0 & $<0.1$ & - & -- \\
\hline NAL-55 & $0.7 \mathrm{Mo}$ & 3.7 & 1.7 & 33.5 \\
\hline NAL-66 & $2.0 \mathrm{Mo}$ & 4.5 & 2.4 & 30.2 \\
\hline NAL-59 & $1.5 \mathrm{Mo}+0.4 \mathrm{Nb}$ & 56.8 & -- & 45.6 \\
\hline NAL-60 & $1.5 \mathrm{Mo}+1.0 \mathrm{Nb}$ & 231.0 & 0.015 & 50.4 \\
\hline NAL-61 & $1.5 \mathrm{Mo}+0.4 \mathrm{Ta}$ & 18.4 & -- & 54.0 \\
\hline NAL-62 & $1.5 \mathrm{Mo}+1.0 \mathrm{Ta}$ & 715.0 & 0.0086 & 57.1 \\
\hline NAL-72 & $1.5 \mathrm{Mo}+0.4 \mathrm{~V}$ & 1.2 & 10.0 & 40.3 \\
\hline NAL-73 & $1.5 \mathrm{Mo}+1.0 \mathrm{~V}$ & 15.4 & 0.50 & 50.8 \\
\hline
\end{tabular}


Figures 12 and 13 show a plot of weight change in the alloys as a function of exposure time at 800 and $1000^{\circ} \mathrm{C}$, respectively. All the alloys exhibited very low weight gain and showed no indication of spalling. At $800^{\circ} \mathrm{C}$, NAL-61 containing tantalum showed the highest weight gain, while NAL-59 containing niobium showed the lowest weight gain. At $1000^{\circ} \mathrm{C}$, the weight gain is almost the same for all the alloys. Note that there is no major difference in oxidation rate at 800 and $1000^{\circ} \mathrm{C}$, indicating excellent oxidation resistance of the $\mathrm{NiAl}$ alloys.

\section{SUMMARY AND CONCLUSIONS}

The objective of this program is to study alloying effects in near-stoichiometric $\mathrm{NiAl}$ for the purpose of improving its mechanical and metallurgical properties for structural applications at high temperatures. Ternary additions of 12 elements, including Fe, Mo, Cr, Ga, Ti, V, Y, $\mathrm{W}, \mathrm{Mn}, \mathrm{Cu}, \mathrm{Ag}$, and $\mathrm{Zn}$, were added to $\mathrm{NiAl}$, and selection of the alloying elements was based on considerations of electronic structure, atom bonding, solubility limit, and APB energy. The alloy ingots containing up to 10 at. \% alloying elements were prepared and fabricated into rod stock by hot extrusion at 900 to $1050^{\circ} \mathrm{C}$.

Our tensile tests indicate that, among the alloying elements added to $\mathrm{NiAl}$, molybdenum is found to be most effective in improving both the ductility at room temperature and strength at elevated temperatures. Alloying with $1.0 \pm 0.6 \%$ Mo almost doubles the room-temperature tensile ductility of $\mathrm{NiAl}$ and triples its yield strength at $1000^{\circ} \mathrm{C}$. The solubility of molybdenum is low in $\mathrm{NiAl}$, and second-phase particles were observed in the alloys containing more than 0.1 at. \% Mo. The particles are effective in retarding recrystallization, and alloying with $0.4 \%$ Mo raises the recrystallization temperature of $\mathrm{NiAl}$ from 800 to $1200^{\circ} \mathrm{C}$.

The high-temperature strength and creep resistance of Mo-modified $\mathrm{NiAl}$ alloys can be substantially improved by alloying with up to 1 at. $\% \mathrm{Nb}$ or $\mathrm{Ta}$. At $1000^{\circ} \mathrm{C}$, niobium is most effective in strengthening $\mathrm{NiAl}$, and a fivefold increase in yield strength is achieved by adding $1 \% \mathrm{Nb}$. Because of the low solubility of niobium and tantalum, fine precipitates $(0.25$ to $1 \mu \mathrm{m}$ ) form in $\mathrm{Nb}$ - and Ta-modified alloys containing molybdenum additions, as evidenced by TEM studies. Burgers vectors were analyzed, and limited results indicate that dislocations in the alloys are of the $<100>$ type. The fine precipitates are expected to contribute to pinning dislocations and enhancing the strength of these alloys. Creep tests at $1.8 \mathrm{MPa}$ and $816^{\circ} \mathrm{C}$ showed that alloying with $1 \% \mathrm{Nb}$ or $\mathrm{Ta}$ extends the rupture life of $\mathrm{NiAl}$ alloys containing $1.5 \%$ Mo by four orders of magnitude. All the alloys exhibited excellent oxidation resistance at 800 and $1000^{\circ} \mathrm{C}$. 
$n$
0
0
0
0
0
$\vdots$
$\vdots$
$\vdots$
$\vdots$
$\vdots$
0
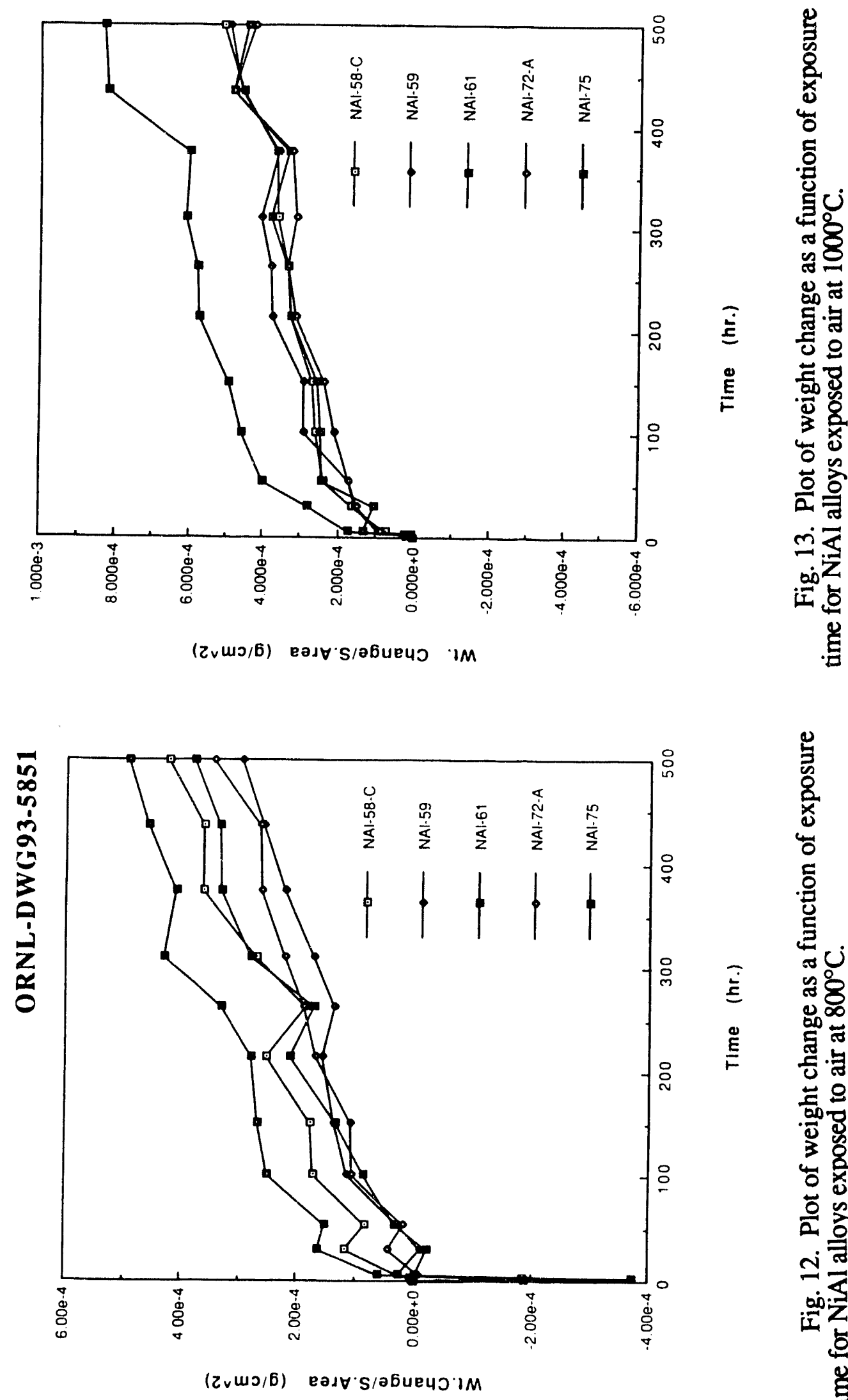

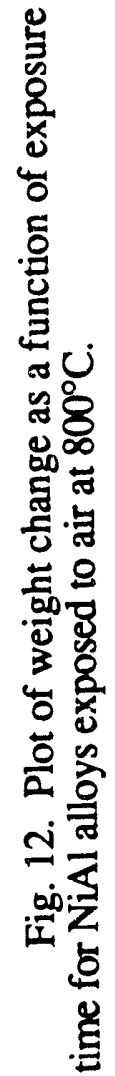


This study of alloying effects provides a critical input for the alloy design of ductile and strong NiAl alloys. Our study identified the following alloy composition (at. \%) with promising properties:

$$
\mathrm{Ni}-(49.1 \pm 0.5) \mathrm{Al}-(1.0 \pm 0.6) \mathrm{Mo}-(0.7 \pm 0.3) \mathrm{Nb} / \mathrm{Ta}-(0 \text { to } 0.02) \mathrm{B}
$$

Note that the nickel and aluminum concentrations in the alloy should be kept at the same level.

\section{ACKNOWLEDGMENTS}

The authors are grateful to M. H. Yoo, C. G. McKamey, and P. Angelini for review and valuable discussions and D. H. Pierce, L. M. Pike, P. A. Ferguson, T. Henson, J. D. Vought, K. S. Blakely, and C. E. Dunn for technical assistance. Thanks are also due to Debbie McCoy, Fay Christie, and Connie Dowker for manuscript preparation; Lisa Kendrick for final report preparation; and Kathy Spence for editing.

\section{REFERENCES}

1. Binary Alloy Phase Diagrams, ed. T. B. Massalski, Vols. 1 and 2, American Society for Metals, Materials Park, Ohio, 1986.

2. E. A. Aitken, pp. 491-516 in Intermetallic Compounds, ed. J. H. Westbrook, Wiley, New York, 1967.

3. J. L. Smialek, Metall. Trans. A 9A, 309 (1978).

4. J. Jedlinski and S. Miowic, Mater. Sci. Eng. 87, 281 (1987).

5. C. A. Barrett, Oxid. Met. 30, 361 (1988).

6. High-Temperature Ordered Intermetallic Alloys, proceedings of Materials Research Society symposium, Vol. 39, ed. C. C. Koch, C. T. Liu, and N. S. Stoloff, Materials Research Society, Pittsburgh, 1985.

7. High-Temperature Ordered Intermetallic Alloys II, proceedings of Materials Research Society symposium, Vol. 81, ed. N. S. Stoloff, C. C. Koch, C. T. Liu, and O. Izumi, Materials Research Society, Pittsburgh, 1987.

8. High-Temperature Ordered Intermetallic Alloys III, proceedings of Materials Research Society symposium, Vol. 133, ed. C. T. Liu, A. I. Taub, N. S. Stoloff, and C. C. Koch, Materials Research Society, Pittsburgh, 1989.

9. A. Ball and R. E. Smallman, Acta Metall. 14, 1517 (1966). 
10. N. J. Zaluzec and H. L. Fraser, Scr. Metall. 8, 1049 (1974).

11. I. Baker and E. M. Schulson, Metall. Trans. A 15A, 1129 (1984).

12. E. M. Grala, pp. 358-404 in Mechanical Properties of Intermetallic Compounds, ed. J. H. Westbrook, Wiley, New York, 1960.

13. K. H. Hahn and K. Vedula, Scr. Metall. 23, 7 (1989).

14. A. G. Rozner and R. J. Wasilewski, J. Inst. Met. 94, 169 (1966).

15. E. P. George and C. T. Liu, J. Mater. Res. 5, 754 (1990).

16. E. P. George, C. T. Liu, and J. J. Liao, in Alloy Phase Stability and Design, proceedings of Materials Research Society symposium, Vol. 186, eds. G. M. Stocks, D. P. Pope, and A. F. Giamei, Materials Research Society, Pittsburgh, 1990.

17. K. Vedula and J. R. Stephens, p. 381 in High Temperature Ordered Intermetallic Alloys, Vol. 81, eds. N. S. Stoloff, C. C. Koch, C. T. Liu, and O. Izumi, Materials Research Society, Pittsburgh, 1987.

18. A. J. Bradley and A. Taylor, Proc. R. Soc. London, A 136, 210 (1932).

19. A. J. Bradley and A. Taylor, Proc. R. Soc. London, A 159, 56 (1937).

20. N. Ridley, J. Inst. Met. 94, 255 (1966).

21. M. J. Cooper, Philos. Mag. 8, 805 (1963).

22. J. H. Westbrook, J. Electrochem. Soc. 103, 54 (1956).

23. C. T. Liu, C. L. White, and J. A. Horton, Acta Metall. 33, 213-19 (1985).

24. T. Takasugi, E. P. George, D. P. Pope, and O. Izumi, Scr. Metall. 19, 551-56 (1985).

25. T. Ogura, S. Hanada, T. Masumoto, and O. Izumi, Metall. Trans. A 16A, 441-43 (1985).

26. K. Aoki and O. Izumi, Nippon Kinzoku Gakkaishi 43, 1190 (1979).

27. A. I. Taub, S. C. Huang, and K. M. Chang, Metall. Trans. A 15A, 399 (1984).

28. D. G. Pettifor, New Sci. 110(1510), 48-53 (1986).

29. D. G. Pettifor, J. Phys. C 19, 285-313 (1986).

30. D. G. Pettifor and R. Podloucky, Phys. Rev. Lett. 55, 261 (1985).

31. D. B. Miracle, S. Russell, and C. C. Law, pp. 225-30 in High-Temperature Ordered Intermetallic Alloys III, proceedings of Materials Research Society symposium, Vol. 133, ed. C. T. Liu, A. I. Taub, N. S. Stoloff, and C. C. Koch, Materials Research Society, Pittsburgh, 1989. 
32. R. Darolia, D. F. Lahrman, R. D. Field, and A. J. Freeman, pp. 113-18 in High-Temperature Ordered Intermetallic Alloys III, proceedings of Materials Research Society symposium, Vol. 133, ed. C. T. Liu, A. I. Taub, N. S. Stoloff, and C. C. Koch, Materials Research Society, Pittsburgh, 1989.

33. K. Vedula, V. Pathare, I. Aslamidis, and R. H. Titran, pp. 411-21 in High-Temperature Ordered Intermetallic Alloys, proceedings of Materials Research Society symposium held at Boston, Maine, Vol. 39, ed. C. C. Koch, C. T. Liu, and N. S. Stoloff, Materials Research Society, Pittsburgh, 1985.

34. G. W. Marshall and J. O. Brittain, Metall. Trans. A 6A, 921-26 (1975).

35. W. Yang, R. A. Dodd, and P. R. Strutt, Metall. Trans. A 3, 2049-2054 (1972). 
ORNL/TM-12200

\section{INTERNAL DISTRIBUTION}

1-2. Central Research Library

3. Document Reference Library

4-5. Laboratory Records Department

6. Laboratory Records, ORNL-RC

7. ORNL Patent Section

8-10. M\&C Records Cffice

11. D. J. Alexander

12. J. D. Allen, Jr.

13. P. F. Becher

14. E. E. Bloom

15. R. A. Bradley

16. C. R. Brinkman

17. W. H. Butler

18. R. S. Carlsmith

19. D. F. Craig

20. S. A. David

21. R. M. Davis

22. J. H. DeVan

23. H. W. Hayden

24-28. E. P. George

29. R. L. Heestand

30-34. J. A. Horton

35. L. L. Horton

36. C. R. Hubbard

37. T. J. Huxford

38. J. R. Keiser

39. E. A. Kenik

40. J. F. King

41-45. E. H. Lee
46. H. Lin

47-51. C. T. Liu

52. K. C. Liu

53. G. M. Ludtka

54. G. M. Ludtka

55. P. J. Maziasz

56. H. E. McCoy, Jr.

57. C. G. McKamey

58. M. K. Miller

59. R. N. Morris

60. M. Olszewski

61. W. D. Porter

62. P. L. Rittenhouse

63. M. L. Santella

64. J. H. Schneibel

65. P. S. Sklad

66. V. K. Sikka

67. C. J. Sparks, Jr.

68. V. J. Tennery

69. P. F. Tortorelli

70. S. Viswanathan

71. J. R. Weir, Jr.

72. Y. A. Chang (Consultant)

73. H. W. Foglesong (Consultant)

74. J. J. Hren (Consultant)

75. M. L. Savitz (Consultant)

76. J. G. Simon (Consultant)

77. K. E. Spear (Consultant)

\section{EXTERNAL DISTRIBUTION}

78. CARPENTER TECHNOLOGY CORPORATION, 101 West Bern St., P.O. Box 4662, Reading, PA 19612-4662

N. Fiore

79. COORS CERAMIC COMPANY, Technical Operations and Engineering, 600 Ninth St., Golden, CO 80401

D. Wirth, Vice President 
80. DARMOUTH COLLEGE, Thayer School of Engineering, Hanover, NH 03755

I. Baker

81. DOW CHEMICAL COMPANY, INC., Central Research, Catalysis Laboratory, 1776 Building, Midland, MI 49674

R. D. Varjian

82. ELECTRICAL POWER RESEARCH INSTITUTE, Nuclear Plant Corrosion Control, 3412 Hillview Ave., Palo Alto, CA 94303

M. M. Behravesh

83. LEHIGH UNIVERSITY, Bethlehem, PA 18015

A. K. MacPherson

84-85. LOS ALAMOS NATIONAL LABORATORY, P. O. Box 1663, G7771, Los Alamos, NM 87545

J. J. Petrovic

A. D. Rollett

86. NATIONAL INSTTTUTE OF STANDARDS AND TECHNOLOGY, Metallurgy Division, Building 223, Room B248, Gaithersburg, MD 20899

R. E. Ricker

87. NAVAL RESEARCH LABORATORY, Materials Science and Component Technology, Code 6000, Building 43, Room 212, Washington, DC 20375-5000

B. B. Rath, Associate Director of Research

88. NORTH CAROLINA STATE UNIVERSITY, Department of Materials Engineering, Yarborough Dr., Raleigh, NC 27695-7907

C. C. Koch

89. UNIVERSITY OF CINCINNATI, Materials Science and Engineering Department, ML 012, Cincinnati, OH 45221

J. A. Sekhar

90. UNIVERSITY OF TENNESSEE, Department of Materials Science and Engineering, Knoxville, TN 37996-2200

B. F. Oliver 
91. VANDER LINDEN AND ASSOCIATES, 5 Brassie Way, Littleton, CO 80123

C. R. Vander Linden

92. WISCONSIN CENTRIFUGAL, 905 E. St. Paul Ave., Waukesha, WI 53188-3898

T. J. Devine

93-94. U.S. DOE, Forrestal Building, 1000 Independence Ave., SW, Washington, DC 20585

M. E. Gunn, Jr. (CE-232)

P. H. Salmon-Cox (CE-23)

95. U.S. DOE, ADVANCED INDUSTRIAL CONCEPTS DIVISION, Advanced Industrial Concepts Materials Program, 1000 Independence Ave., SW, Washington, DC 20585

C. A. Sorrell (CE-232)

96-97. U.S. DOE, OAK RIDGE FIELD OFFICE, P.O. Box 2008, Oak Ridge, TN 37831

Deputy Assistant Manager for Energy Research and Development E. E. Hoffman

98-99. U.S. DOE, OFFICE OF SCIENTIFIC AND TECHNICAL INFORMATION, P.O. Box 62, Oak Ridge, TN 37831

For distribution by microfiche as shown in DOE/OSTI-4500, Distribution Category UC-310 [Industrial Programs (General)] 

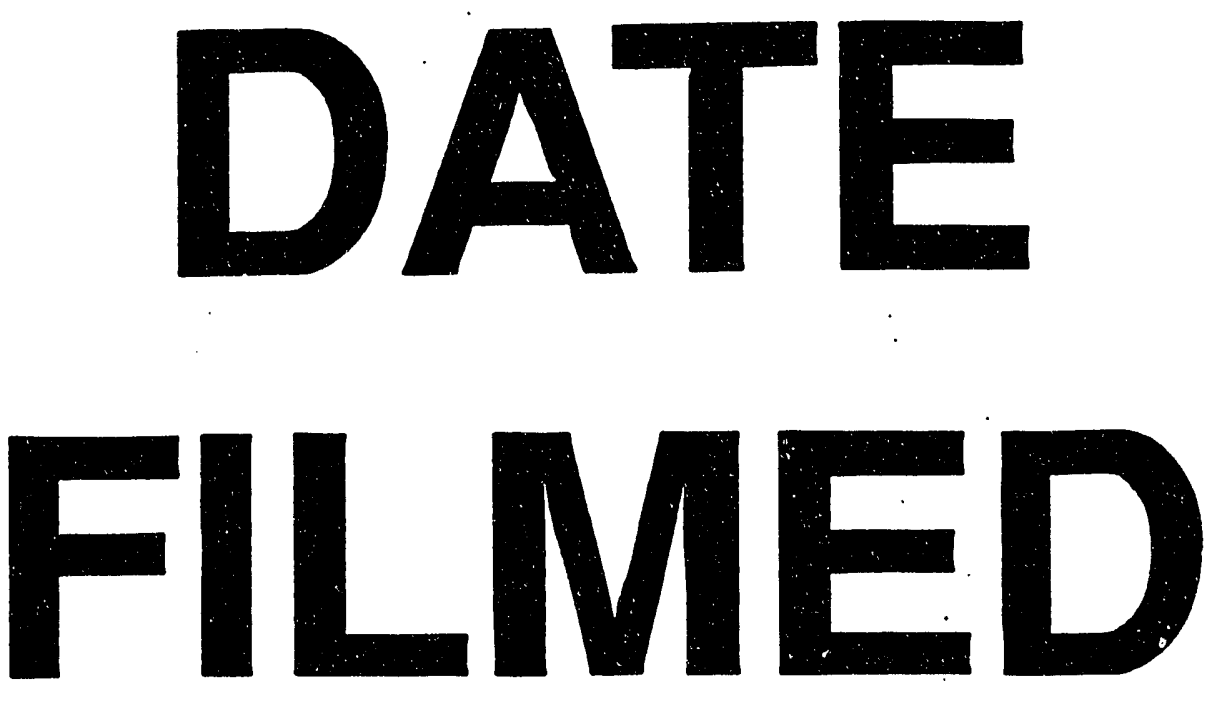

$11 / 17 / 93$
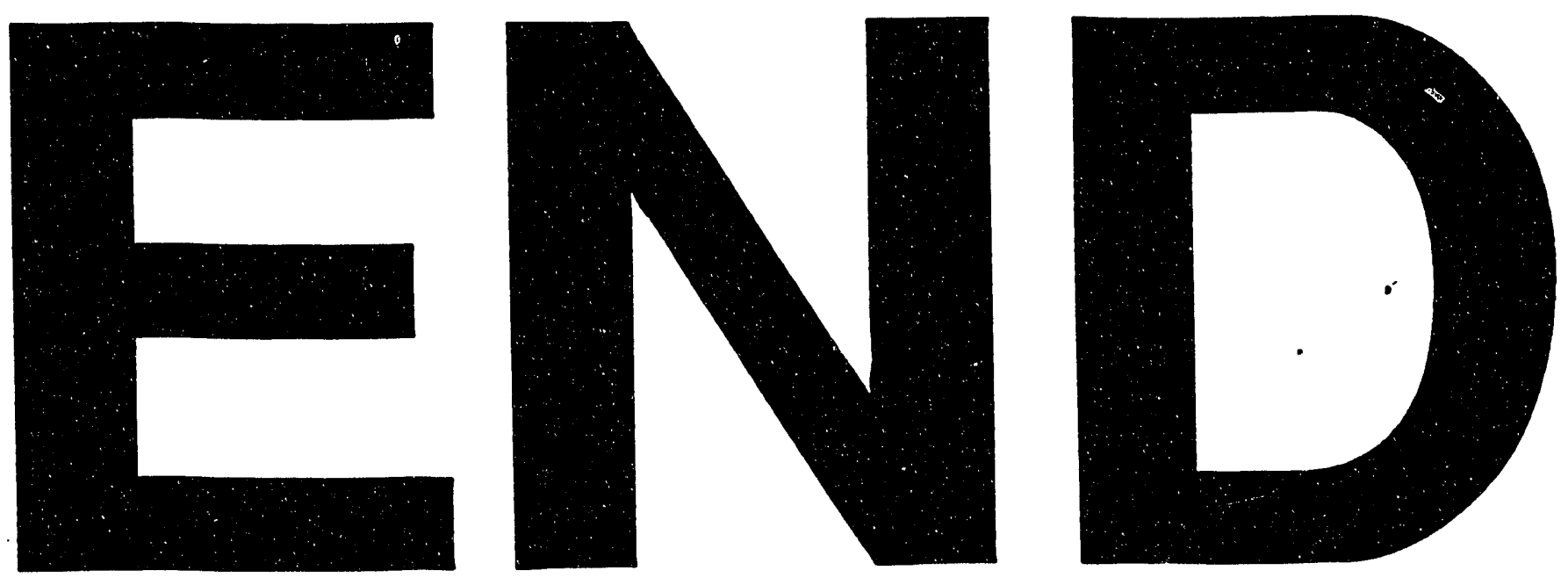
